\title{
Article \\ HrpL Regulon of Bacterial Pathogen of Woody Host Pseudomonas savastanoi pv. savastanoi NCPPB 3335
}

\author{
Alba Moreno-Pérez ${ }^{1,2}$, Cayo Ramos ${ }^{1,2, *(\mathbb{D})}$ and Luis Rodríguez-Moreno ${ }^{1,2, *}$ \\ 1 Área de Genética, Facultad de Ciencias, Campus Teatinos s/n, Universidad de Málaga, \\ E-29010 Málaga, Spain; albamp@uma.es \\ 2 Departamento de Microbiología y Protección de Cultivos, Instituto de Hortofruticultura Subtropical y \\ Mediterránea «La Mayora», Extensión Campus de Teatinos, Universidad de Málaga-Consejo Superior de \\ Investigaciones Científicas (IHSM-UMA-CSIC), E-29010 Málaga, Spain \\ * Correspondence: crr@uma.es (C.R.); lgrodriguez@uma.es (L.R.-M.); \\ Tel.: +34-952-132-146 (C.R.); +34-952-132-131 (L.R.-M.)
}

Citation: Moreno-Pérez, A.; Ramos, C.; Rodríguez-Moreno, L. HrpL Regulon of Bacterial Pathogen of Woody Host Pseudomonas savastanoi pv. savastanoi NCPPB 3335.

Microorganisms 2021, 9, 1447. https:/ / doi.org/10.3390/microorganisms 9071447

Academic Editors: Rafael Rivilla and Jacob G. Malone

Received: 9 June 2021

Accepted: 29 June 2021

Published: 5 July 2021

Publisher's Note: MDPI stays neutral with regard to jurisdictional claims in published maps and institutional affiliations.

Copyright: (c) 2021 by the authors. Licensee MDPI, Basel, Switzerland. This article is an open access article distributed under the terms and conditions of the Creative Commons Attribution (CC BY) license (https:/ / creativecommons.org/licenses/by/ $4.0 /)$.

\begin{abstract}
The Pseudomonas savastanoi species comprises a group of phytopathogenic bacteria that cause Symptoms of disease in woody hosts. This is mediated by the rapid activation of a pool of virulence factors that suppress host defences and hijack the host's metabolism to the pathogen's benefit. The $h r p L$ gene encodes an essential transcriptional regulator of virulence functions, including the type III secretion system (T3SS), in pathogenic bacteria. Here, we analyzed the contribution of HrpL to the virulence of four pathovars (pv.) of P. savastanoi isolated from different woody hosts (oleander, ash, broom, and dipladenia) and characterized the HrpL regulon of $P$. savastanoi pv. savastanoi NCPPB 3335 using two approaches: whole transcriptome Sequencing (RNA-seq) and the bioinformatic prediction of candidate genes containing an hrp-box. Pathogenicity tests carried out for the P. savastanoi pvs. showed that HrpL was essential for symptom development in both non-host and host plants. The RNA-seq analysis of the HrpL regulon in P. savastanoi revealed a total of 53 deregulated genes, 49 of which were downregulated in the $\Delta h r p L$ mutant. Bioinformatic prediction resulted in the identification of 50 putative genes containing an hrp-box, 16 of which were Shared with genes previously identified by RNA-seq. Although most of the genes regulated by HrpL belonged to the T3SS, we also identified some genes regulated by HrpL that could encode potential virulence factors in P. savastanoi.
\end{abstract}

Keywords: P. savastanoi pv. savastanoi (Psv); type III secretion system (T3SS); HrpL regulon; RNA-seq analysis; $h r p$-box prediction; virulence factors

\section{Introduction}

The type III secretion system (T3SS) is considered one of the most relevant virulence mechanisms in animal and plant pathogenic bacteria. The T3SS is a complex membraneembedded nanomachine through which Gram-negative bacteria translocate a set of proteins, known as type III effectors (T3Es), into the cytoplasm of host cells [1-7]. Structurally, the injectosome is made up of more than 20 proteins and is the most complex secretion system in bacteria [8]. From a functional point of view, the translocation of T3Es contributes to perturbing host cellular functions to facilitate bacterial survival and host colonization [6,9-13]. The T3SS is essential for Pseudomonas syringae pathogens to thrive in plant tissues. Although the evolution of the T3SS remains controversial, phylogenetic analysis through amino acid sequence comparison suggests that the T3SS first emerged in plant pathogens as an evolutionary adaptation of the flagellar export apparatus [4].

The $P$. syringae species complex is considered one of the most relevant phytopathogenic bacteria worldwide, due to its capacity to infect the phyllosphere and cause disease in a diverse range of cultivated, ornamental, and wild plants [14,15]. The complex comprises 13 phylogroups (PGs) encompassing 15 Pseudomonas species [16,17] that can be divided 
into about 65 pathovars (pv.) defined by their host ranges [18]. Except for some naturally occurring non-pathogenic P. syringae strains that lack the canonical T3SS [19-21], most of the Strains included in the P. syringae complex require a functional T3SS for pathogenesis in susceptible plants $[4,22,23]$.

The T3SS in P. syringae is encoded and regulated by the products of the hypersensitive response and pathogenicity $(h r p)$ and hypersensitive response and conserved $(h r c)$ gene clusters, which are included in a tripartite pathogenicity island together with other genes that encode accessory and conserved T3Es [24,25]. After translocation into the host cytoplasm, T3Es subvert host cellular functions, facilitating bacterial survival and host colonization [6,9-13]. The recognition of T3Es or their activity by the plant immune System, through resistance proteins or other mechanisms, induces the host's hypersensitive response (HR), a localized plant cell death response that limits bacterial growth [26]. For this reason, the T3SS and its T3E repertoire have been recognized as the main determinants of host specificity in P. syringae [27-29].

The transcriptional regulation of T3SS' structural components and their associated T3E repertoire in P. syringae is dependent on the HrpL regulator, which encodes an alternate Sigma $(\sigma)$ factor that recognizes a conserved promoter sequence (GGAACC-N15/16CCACNNA), known as the hrp-box [30]. HrpL's expression depends on the $\sigma^{54}$ factor RpoN and two transcriptional activators, HrpR and HrpS, which work as heterodimers and cooperate with $\sigma^{54}$ to promote the expression of $h r p L$ [31,32]. Recent studies have clearly shown that the Signaling pathways and molecular mechanisms involved in T3SS regulation in P. syringae are a complex, intricate network [33] involving dozens of regulatory proteins [8,34], second messenger molecules such as c-di-GMP [35], and variations in the physicochemical conditions during host colonization [36].

Pseudomonas savastanoi belongs to the PG3 group of the P. syringae complex; the unique PG includes knot-producing bacteria in woody hosts $[16,37,38]$. P. savastanoi comprises five pathovars that cause diseases in woody plants: pv. savastanoi (Psv, isolated from olive), pv. nerii (Psn, isolated from oleander), pv. fraxini (Psf, isolated from ash), pv. retacarpa (Psr, isolated from broom), and pv. mandevillae (Psm, isolated from dipladenia) [37,39]. In the Psv and Psn strains, the functionality of the T3SS has been shown to be essential for knot formation in the respective hosts and the induction of a characteristic HR in resistant hosts [37,40-43]. Recent comparative genomics analysis of strains belonging to these five pathovars identified the codification of highly conserved canonical T3SSs in strains of Psf, Psm, and Psr. However, their functionality and roles in pathogenesis in these three pathovars have not yet been established [39,44,45]. Furthermore, and as previously reported for Psv NCPPB 3335 [46], an additional T3SS resembling that found in Rhizobiaceae was also found in the other pathovars [39,44]. The relevance of T3SS regulation by HrpL in P. savastanoi is evidenced by the inability to induce knot formation in olive plants and to induce HR in tobacco plants by using a $\triangle h r p L$ mutant of the model Psv strain NCPPB 3335 [47]. Furthermore, pathovar-specific regulation of the T3SS and its T3E genes has been identified in Psv, Psn, and Psf, suggesting a possible role in host range, depending on the physiological conditions found in the apoplast, or the extracellular space of the host plant tissues [45].

The global regulation of transcription by HrpL in the P. syringae complex has been approached using microarrays or RNA-seq strategies. However, the HrpL regulon has only been defined in P. syringae strains isolated from herbaceous hosts $[48,49]$, and no data are available for strains isolated from woody hosts. Here, we constructed HrpL mutants of model Psn, Psm, Psf, and Psr strains to study the role of this regulator in the pathogenicity of $P$. savastanoi strains isolated from other woody hosts. Then, we defined the HrpL regulon of Psv NCPPB 3335, the only P. savastanoi strain whose chromosome [44,46] and plasmids [50] have been fully sequenced. For this purpose, we used two approaches: (i) the comparative transcriptomic analysis (RNA-seq) of wild-type Psv NCPPB 3335 and its $\Delta h r p L$ mutant, and (ii) the bioinformatic prediction of $h r p$-box promoters in the genome of this strain. A comparison of the results obtained from these analyses with those 
previously reported for $P$. syringae strains isolated from herbaceous hosts allowed us to unravel novel HrpL-dependent genes that may play a role in the virulence of $P$. savastanoi and the interactions of bacterial pathogens with woody hosts.

\section{Materials and Methods}

\subsection{Bacterial Strain, Plasmids, and Growth Conditions}

The bacterial strains and plasmids used in this study are described in Tables S1 and S2, respectively. All the $P$. savastanoi strains were grown at $28{ }^{\circ} \mathrm{C}$ in lysogeny broth (LB) medium [51] without glucose and containing $0.5 \% \mathrm{NaCl}$, in King's B (KB) medium [52] or in Super Optimal Broth (SOB) medium [53]. Escherichia coli strains were grown in LB medium at $37^{\circ} \mathrm{C}$. When required, the medium was supplemented with the following: for P. savastanoi: ampicillin (Ap) $(400 \mu \mathrm{g} / \mathrm{mL})$, kanamycin $(\mathrm{Km})(7 \mu \mathrm{g} / \mathrm{mL})$, nitrofurantoin (Nf) $(25 \mu \mathrm{g} / \mathrm{mL})$, and cycloheximide (Ch) $(100 \mu \mathrm{g} / \mathrm{mL})$; for E. coli: Ap $(100 \mu \mathrm{g} / \mathrm{mL})$ and $\mathrm{km}$ $(50 \mu \mathrm{g} / \mathrm{mL})$.

\subsection{Construction of P. savastanoi Mutants}

To construct the hrpL mutants, the complete gene was removed from model strains of Psn, Psm, Psf, and Psr. These mutants were constructed using the pIAC4-Km plasmid previously described [47] (Table S2), which contains a DNA fragment of approximately $1.2 \mathrm{~kb}$ corresponding to the $5^{\prime}$ and $3^{\prime}$ flanking regions of the Psv NCPPB $3335 \mathrm{hrpL}$ gene and the nptII (Km)-resistance gene. This plasmid was electroporated into Psn Psn23, Psm Ph3, Psf NCPPB 1006, and Psr CECT 4861, as previously described [54]. The mutants were Screened and verified as previously described [47]. Thereafter, the kanamycin gene was removed using the pFLP2 plasmid [55].

\subsection{Plant Bioassays}

The Nicotiana tabacum var. Newdel and Solanum lycopersicum var. MoneyMaker plants used in the HR assays were 3 months and 4-6 weeks old, respectively. The plants were grown with a photoperiod of $16 \mathrm{~h}$ of light and $8 \mathrm{~h}$ of darkness, with day/night temperatures of 26 and $22{ }^{\circ} \mathrm{C}$, respectively. The leaves were infiltrated with bacterial suspensions in $10 \mathrm{mM} \mathrm{MgCl}_{2}\left(5 \times 10^{7}\right.$ to $\left.1 \times 10^{8} \mathrm{CFU} / \mathrm{mL}\right)$ of the $\Delta h r p L$ mutants using a blunt syringe. The generated symptoms were captured with a high-resolution digital camera (Nikon DXM 1200; Nikon Corporation, Tokyo, Japan) at 48 h post-inoculation.

The pathogenicity of the $\Delta h r p L$ mutants was analyzed for Nerium oleander plant accession "pink" (single pink flowers) supplied by Viveros Guzmán (Málaga, Spain), Fraxinus excelsior and Retama sphaerocarpa plants native to Valladolid and supplied by Viveros Fuenteamarga (Valladolid, Spain), or Mandevilla spp. var. red flowers supplied by New Plants Motril SA (Motril, Spain). Two plants per strain were inoculated, as previously described in [44]. The number of wound sites infected per plant varied between 10 and 12, depending on the Size of the plant.

\subsection{Preparation of Samples for RNA-Seq Analysis}

A pre-inoculum of $20 \mathrm{~mL}$ of the wild-type P. savastanoi pv. savastanoi NCPPB 3335 and its $\Delta h r p L$ mutant was grown overnight in $\mathrm{KB}$ medium at $28^{\circ} \mathrm{C}$. The cells were diluted in 2 cultures of $110 \mathrm{~mL}$ of fresh $\mathrm{KB}$ medium at an $\mathrm{OD}_{600}$ of 0.1 and incubated with agitation at $28{ }^{\circ} \mathrm{C}$ to an $\mathrm{OD}_{600}$ of 0.5 (approximately $5 \times 10^{7} \mathrm{CFU} / \mathrm{mL}$ ). Then $48 \mathrm{~mL}$ of each culture was pelleted; one of these was frozen, and the other was washed twice with $10 \mathrm{mM} \mathrm{MgCl} 2$ and resuspended in the Same volume of Hrp-inducing medium [56]. After $6 \mathrm{~h}$ of incubation, each culture was divided into 6 samples of $8 \mathrm{~mL}$ and pelleted. For each strain, there were 2 biological replicates divided into $8 \mathrm{~mL}$ samples. A sample per biological replicate and strain was processed for RNA isolation using the RNAeasy Mini Kit (Qiagen, Hilden, Germany). Isolated total RNA was treated twice with a TURBO DNA-free Kit (Invitrogen, Carlsbad, CA, USA). The RNA concentration was determined spectrophotometrically, and its integrity was assessed by agarose gel electrophoresis. Before Sequencing, we performed 
RT-qPCR on genes ( $r r p A, \operatorname{avrPto1}$, and hopAO2) whose expression was already known to be regulated by HrpL (Figure S1). This confirmed that the expression of those 3 genes was repressed in the RNA samples obtained from the hrpL mutants. Two independent RNA extractions (two biological replicates) from each strain were Sent to the Ultrasequencing Service of the University of Malaga, where the necessary quality checks were carried out and RNA sequencing was performed. Sample quality control was performed with a LabChip RNA 6000 Pico (Agilent Technologies, Santa Clara, CA, USA). An Illumina Ribo-Zero Plus rRNA Depletion Kit (Illumina, San Diego, CA, USA) was used for the degradation of ribosomal RNA. The libraries were prepared with a TruSeq Stranded mRNA Kit (Illumina, San Diego, CA, USA), and sequencing was performed on an Illumina NextSeq550.

\subsection{Sequence Mapping and Analysis}

The RNA reads were analyzed by the Ultrasequencing Service of the University of Malaga. The Illumina adapters, lower-quality bases, and ribosomal sequences were removed using SeqTrimNext (https: / / rubygems.org/gems/seqtrimnext/versions/2.0.60, accessed on 1 June 2021). Quality control was performed with the FastQC software. Then, the reads were aligned to the complete Sequence of the chromosome of Psv NCPPB 3335 (accession number: NZ_CP008742.1) and those of its 3 native plasmids (pPsv48A, FR820585.2; pPsv48B, FR820586.1; pPsv48C, FR820587.2) using Bowtie 2 (v. 2.2.9) [57]. Differential gene expression and transcript abundance were calculated using the Tuxedo Suite [58] with some modifications. Within this Suite, the Cufflinks program was used to estimate the aligned readings in the different transcripts and estimate their abundance. The fragments per kilobase per million mapped reads (FPKM) values were used to normalize and quantify gene expression. A false discovery rate (FDR) with a significance level of 0.05 ( $q$ value) and a minimum $\log _{2}$ (fold change) of \pm 0.5 was used to judge the Significance of differences in gene expression. A graphical representation of the differential expression results was constructed using the cummeRbund package in $R$ [59].

\subsection{RT-qPCR Assays}

For quantitative real-time PCR (RT-qPCR), DNA-free total RNA obtained as described in the previous section was used. In this procedure, $1 \mu \mathrm{g}$ of DNA-free total RNA was retrotranscribed to cDNA using a cDNA iScript ${ }^{\mathrm{TM}}$ cDNA synthesis kit (Bio-Rad, Hercules, CA, USA) and random hexamers. The RT-qPCR primers were designed with free online Software according to the instructions previously described (Table S3) [60]. The primer efficiency tests, RT-qPCR, and confirmation of amplification reactions were assessed according to the criteria previously described [61]. Each reaction was carried out initially for $2 \mathrm{~min}$ at $95^{\circ} \mathrm{C}$, followed by 45 cycles of PCR $\left(95^{\circ} \mathrm{C}\right.$ for $15 \mathrm{~s}$ and $59{ }^{\circ} \mathrm{C}$ for $\left.30 \mathrm{~s}\right)$. The relative transcript abundance was calculated using the $\Delta \Delta$ cycle-threshold (Ct) method [62]. The data obtained were normalized to the gyr $A$ housekeeping gene and represented as fold change in expression compared with the expression of each gene in the wild-type Strain. The relative expression ratio was calculated as the difference in the $\mathrm{Ct}$ of the gene of interest and gyrA $(\Delta \mathrm{Ct}=\mathrm{Ctgen}$ of interest $-\mathrm{Ctgyr} A)$. One PCR cycle represents a twofold difference in template abundance; therefore, fold change values were calculated as $2^{-\Delta \Delta \mathrm{Ct}}$, as previously described $[63,64]$.

\subsection{Prediction of HrpL-Dependent Genes}

To search for HrpL-dependent genes, we used an ad hoc pipeline considering the presence of potential HrpL boxes (hrp-boxes) 500 nucleotides upstream of the Start codon, as previously described [65]. To identify novel hop genes, we analyzed the N-terminal sequence features of the Selected genes using EffectiveDB [66].

\subsection{Bioinformatic Characterization of Identified Genes}

A comparison was made of the genes identified in this study with the genes whose dependence on HrpL was previously demonstrated by RNA-seq in 6 strains of the Pseu- 
domonas syringae complex isolated from herbaceous hosts: P. syringae pv. tomato (Pto) DC3000, P. syringae pv. phaseolicola (Pph) 1448A, P. syringae pv. syringae (Psy) B728A, $P$. syringae pv. lachrymans (Pla) 107, P. syringae pv. japonica (Pja) MAFF 301072, and P. syringae pv. oryzae (Por) 1_6 [48,49]. This comparison was made by blastp using Geneious 8.1.9 [67]. In addition, a more Specific search looking for protein domains was carried out with Pfam [68] and HHPred [69].

\section{Results}

3.1. HrpL of P. savastanoi Pathovars Is Required for the Induction of Hypersensitive Response in Non-Susceptible Hosts and Symptom Development in Susceptible Hosts

The type III secretion system has been described as a key virulence factor in Psv [42,43,47]. To analyze the role of HrpL in the virulence of Psn, Psm, Psf, and Psr, we generated $\Delta h r p L$ mutants of Psn Psn23, Psm Ph3, Psf NCPPB 1006, and Psr CECT 4861. First, we analyzed the capacity of $P$. savastanoi strains to induce HR in tobacco plants, a non-susceptible host (Figure 1a). As previously reported, the infection of Psv NCPPB 3335, included as positive control, induced characteristic HR symptoms $24 \mathrm{~h}$ post-inoculation (Figure 1a). Out of the four remaining pathovars, Psf NCPPB 1006 and Psr CECT 4861 were also able to induce HR symptoms in tobacco leaves. However, no HR symptoms were observed on tobacco leaves infiltrated with wild-type Psn Psn 23 and Psm Ph3 after 24 h (Figure 1a). Based on this result, we carried out infiltration assays in tomato plants (Figure 1b). The Same as the positive control, all the pathovars were able to induce HR symptoms on tomato leaves after $24 \mathrm{~h}$. However, none of the $\triangle h r p L$ mutants were able to induce the formation of HR symptoms $24 \mathrm{~h}$ post-inoculation in either tobacco or tomato leaves (Figure 1a,b).

(a)

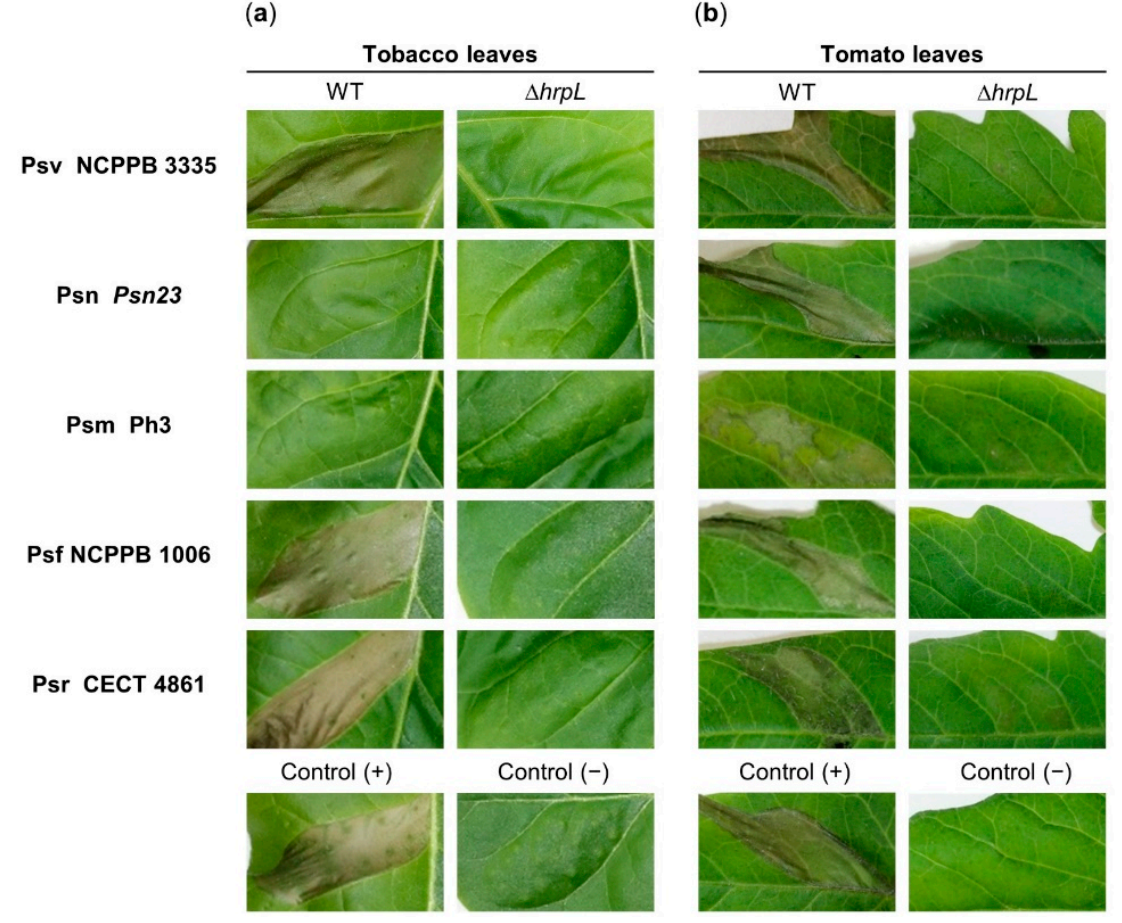

Figure 1. Hypersensitive response (HR) produced by wild-type (WT) strains of P. savastanoi pathovars and their $\Delta h r p L$ mutants in Nicotiana tabacum var. Newdel (tobacco) and Solanum lycopersicum var. Moneymaker (tomato) leaves. (a) HR symptoms induced on tobacco leaves following bacterial infiltration $24 \mathrm{~h}$ post-inoculation. Control (+), leaves inoculated with Pseudomonas syringae pv. tabaci CFBP 1621. (b) HR symptoms induced on tomato leaves after $24 \mathrm{~h}$ post-inoculation. Control (+), leaves inoculated with Pseudomonas syringae pv. tomato DC3000. Control (-), mock-infiltrated plants with $10 \mathrm{mM} \mathrm{MgCl}_{2}$. 
Besides its role in the development of HR symptoms in non-susceptible hosts, HrpL is also required for full symptom induction by Psv in olive plants [47]. To evaluate the contribution of HrpL to the virulence of the other four P. savastanoi pathovars, we carried out pathogenicity tests of $\Delta h r p L$ mutants in their respective host plants (Figure 2). As expected, wild-type Psn Psn23, Psm Ph3, Psf NCPPB 1006, and Psr CECT 4861 were able to induce tissue proliferation (overgrowth) at the inoculation points 90 days post-inoculation. By contrast, none of the inoculated $\Delta h r p L$ mutants showed tumor symptoms at inoculation points that were distinguishable from the mock control plants 90 days post-inoculation (Figure 2).

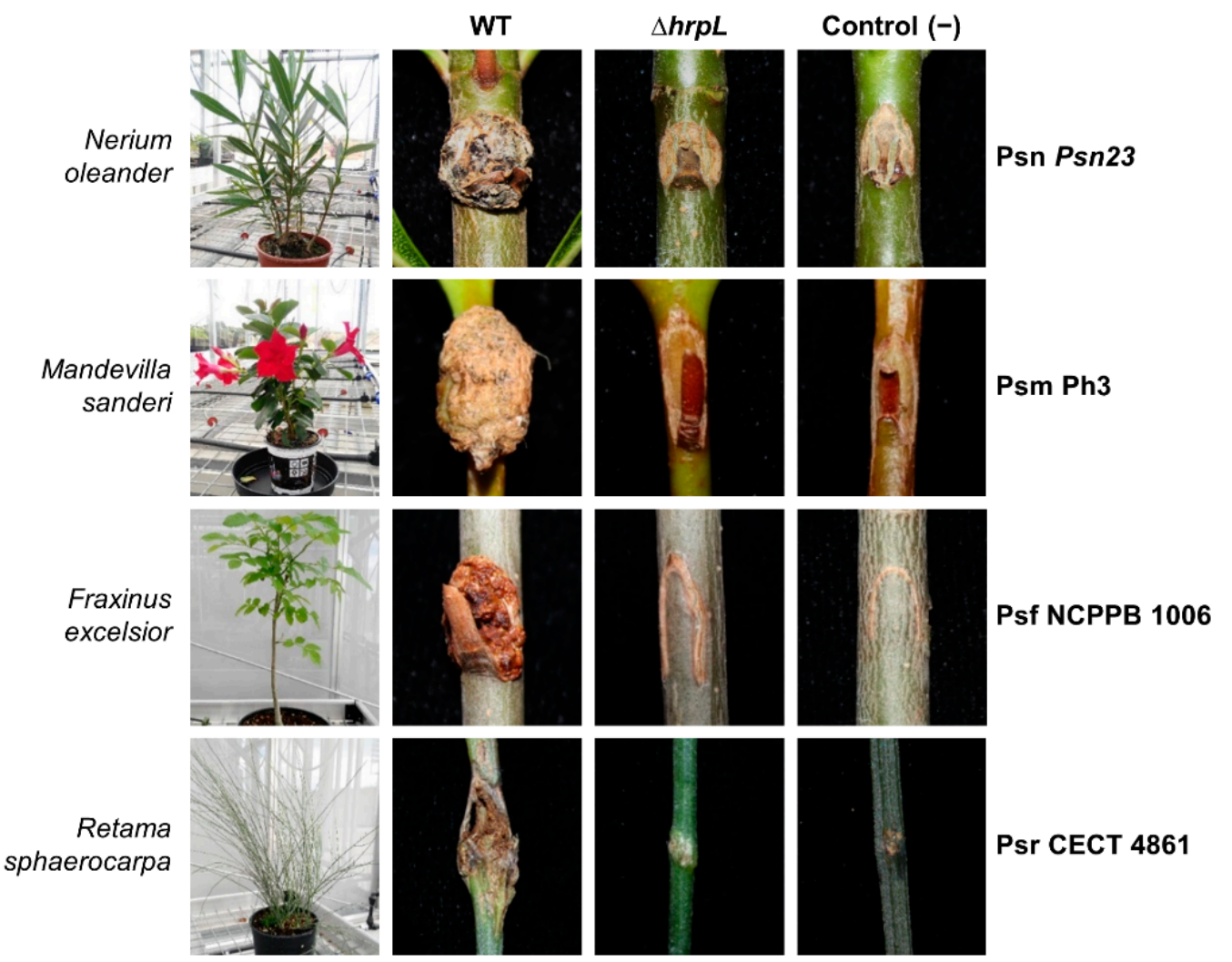

Figure 2. Symptoms induced in oleander, dipladenia, ash, and broom plants 90 days after inoculation with wild-type (WT) strains of P. savastanoi pathovars and their $\Delta h r p L$ mutants. Control (-), plants mock-inoculated with $10 \mathrm{mM} \mathrm{MgCl} 2$.

\subsection{RNA-Seq Transcriptome Profiles for Psv NCPPB 3335 and Its $\triangle$ hrpL Mutant}

Previous work reported that non-effector genes controlled by the HrpL regulon vary across the P. syringae phylogeny [48]. Out of the Six P. syringae strains analyzed by Mucyn and collaborators [48], none was pathogenic in a non-herbaceous plant. Our Psv NCPPB 3335 reference Strain $[44,46]$ and its $\Delta h r p L$ mutant [47] were cultivated on Hrp-inducing medium [56], which simulates in planta apoplastic conditions, to obtain the total RNA. To compare transcript abundance, two biological replicates of each strain were Subjected to Illumina RNA sequencing, and a total of 177.83 million (81.9 million from the wild-type and 95.8 million from the mutant strain) 100-bp paired-end reads was generated (Table S4).

The raw reads were trimmed by removing the adaptor sequences, empty reads, and sequences that did not pass the quality threshold. As a result, 148.1 million high-quality reads $(83.3 \%)$, designated as clean reads, were obtained for both samples (Table S4). By iterative alignment, an average of $99.6 \%$ of the clean reads were mapped to the Psv NCPPB 3335 genome, whereas $0.33 \%$ of the clean reads did not show any identity with the Psv NCPPB 3335 chromosome or any of its three native plasmids. A summary of the Psv NCPPB 3335 genome coverage obtained with the Illumina RNA-seq data is shown in Table S5. Out 
of the 5597 coding sequences contained in the Psv NCPPB 3335 chromosome, 5551 genes $(99.18 \%)$ were covered by Illumina sequencing. Coverage of $99.27 \%$ was obtained for the 5596 genes contained in the Psv NCPPB $3335 \Delta h r p L$ mutant. In addition, the 68, 53, and 51 genes located in the pPsv48A, pPsv48B, and pPsv48C plasmids, respectively, were also covered by the Illumina RNA sequencing (Table S5).

\subsection{Characterization of HrpL Regulon of P. savastanoi pv. savastanoi}

After the bioinformatics processing of the raw data, the cleaned reads of each replicate were compared using the cummeRbund package in R [59]. The distribution of normalized FPKM values did not show significant differences among the biological replicates (Figure S2), suggesting that no technical bias was introduced during library construction and sequencing. The normalized expression levels of the wild-type and mutant strains were compared to detect differentially expressed genes (DEGs). The DEGs were Selected considering a fold change of \pm 0.5 and a statistical value of $q=0.05$ (Figure 3a). A total of 53 DEGs were obtained after the analysis of Psv NCPPB 3335 and its $\triangle h r p L$ mutant strain. Out of the 53 DEGs, four genes (7.55\%) were upregulated, and 49 genes (92.45\%) were downregulated relative to the wild-type Strain (Figure 3b). Based on their annotation, the DEGs were manually classified into six functional categories (Figure 4a): T3SS pilus/chaperones (30 DEGs), type III effectors (14 DEGs), hypothetical proteins (5 DEGs), signaling (2 DEGs), toxins (1 DEG), and secondary metabolism (1 DEG).

(a)

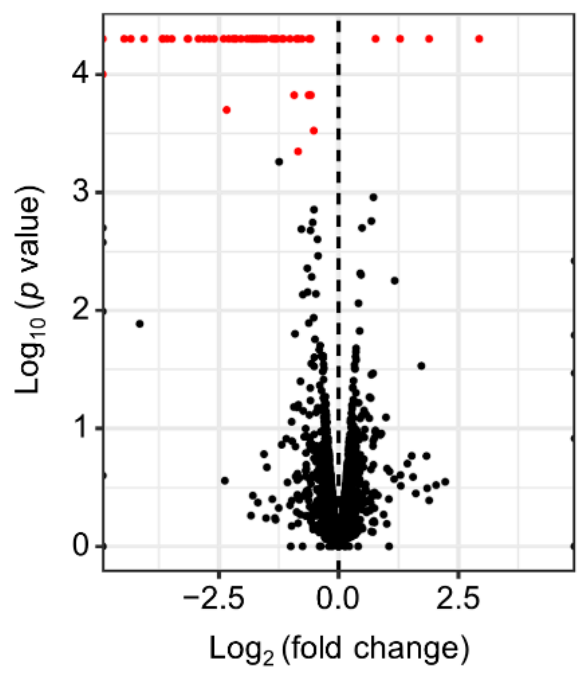

(b)

\section{Upregulated genes}

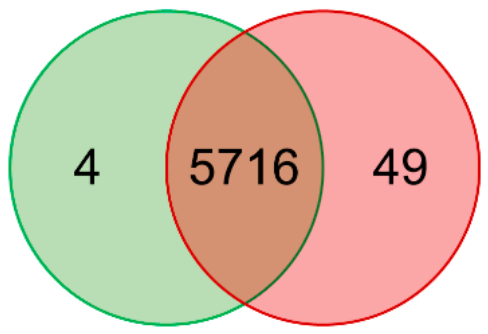

Downregulated genes

Figure 3. Identification of HrpL-dependent genes in P. savastanoi pv. savastanoi NCPPB 3335 by RNA-seq. (a) Volcano plot showing differentially expressed genes (DEGs) between Psv NCPPB 3335 strain and its $\triangle h r p L$ mutant. In red, significant DEGs with $q$ value $<0.05$. (b) Venn diagram of significantly upregulated and downregulated genes in $\triangle h r p L$ mutant relative to wild-type Strain in RNA-seq analysis.

To obtain a more complete picture of the HrpL regulon in P. savastanoi, we performed a bioinformatics search of genes that could putatively be under the regulation of an hrp-box. To this end, we used an ad hoc pipeline considering two criteria: the N-terminal sequence features [66], and the presence of potential hrp-box 500 nucleotides upstream of the Start codon [65]. A total of 50 bioinformatically predicted genes (BPGs) were identified as candidate genes containing a potential hrp-box in their promoter regions. Like the DEGs identified by RNA-seq, the BPGs showed a similar functional categorization, except for the toxin category, which was absent, and the presence of transporters and "others" as additional categories (Figure 4b). Similar to the DEGs, T3SS pilus/chaperones (10 BPGs), type III effectors (10 BPGs), and hypothetical proteins (10 BPGs) were the most represented categories of BPGs. The Signaling category, with 6 BPGs, was also significantly represented 
compared with the two DEGs identified by RNA-seq. Interestingly, a Venn diagram representation shows that only 19 out of the 49 DEGs and 50 BPGs were common to both in vitro and in silico analysis (Figure 4c, Table S6), suggesting that both experimental approaches provide valuable and complementary information.

(a)

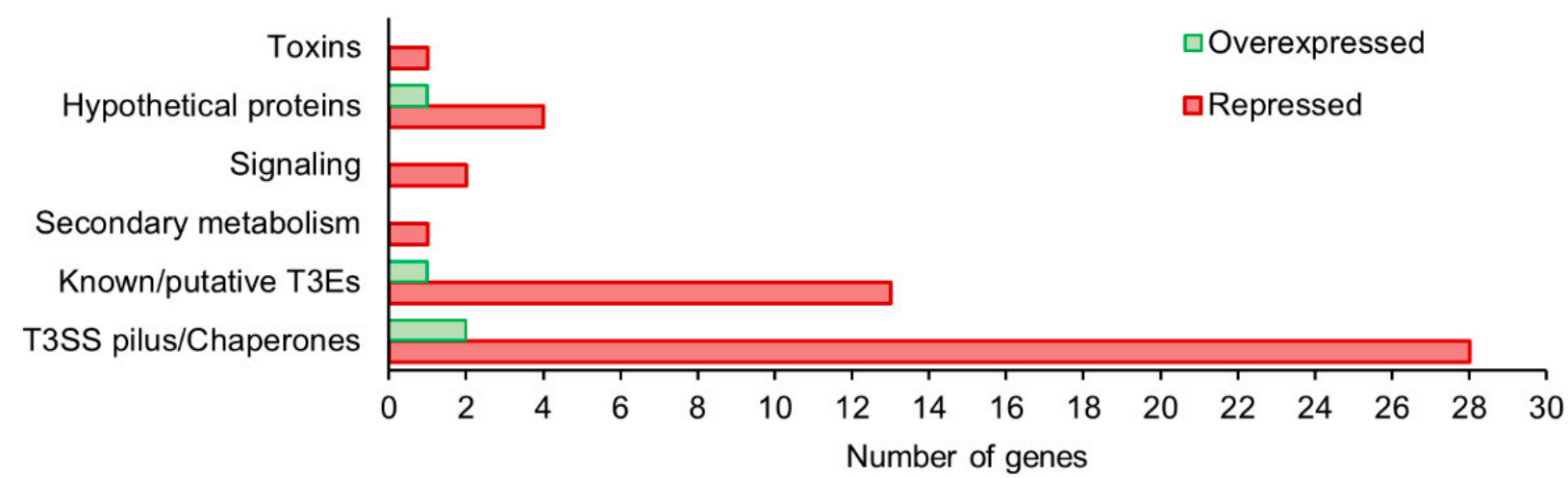

(b)

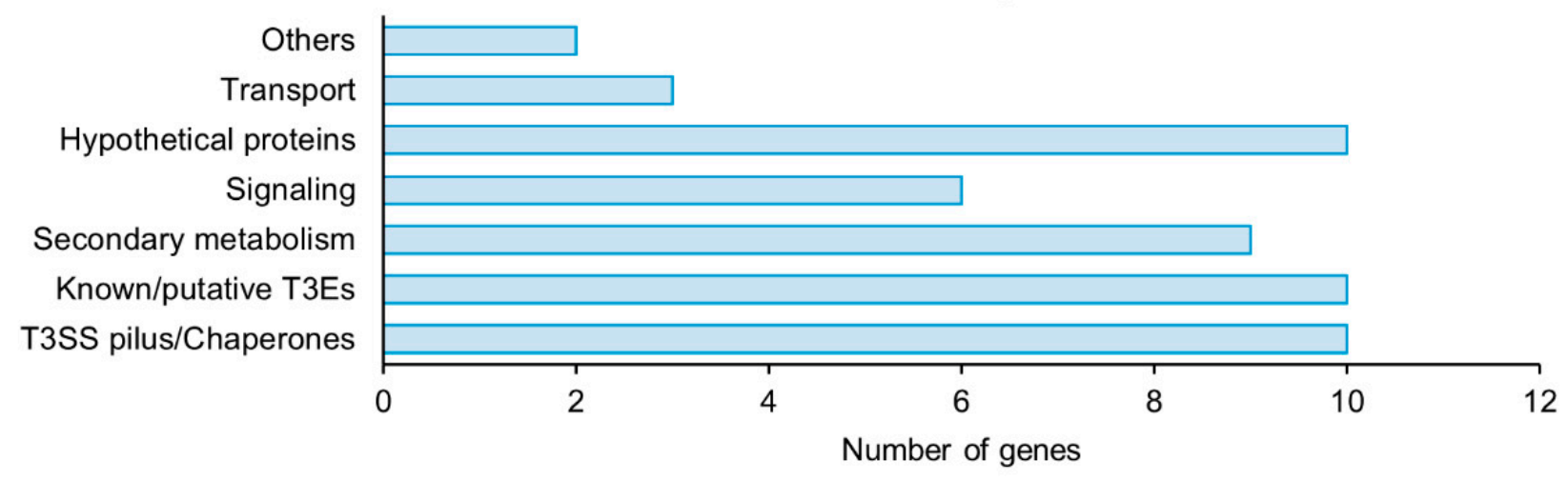

(c)

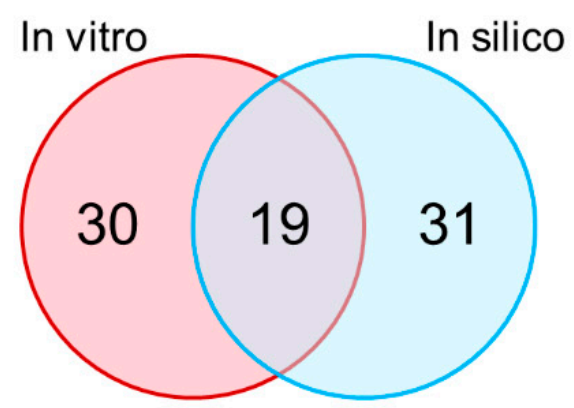

Figure 4. Classification into functional categories of HrpL regulon in P. savastanoi pv. savastanoi NCPPB 3335. Genes were manually classified into functional categories based on their annotation and/or annotation of encoded proteins showing highest homology in a blastp analysis (https: / / www.ncbi.nlm.nih.gov/, accessed on 1 June 2021). (a) Classification into functional categories of differentially expressed genes (DEGs) identified by RNA-seq. Green and red represent upregulated and downregulated genes, respectively, in $\Delta h r p L$ mutant relative to wild-type Strain. (b) Classification into functional categories of bioinformatically predicted genes (BPGs) with putative $h r p$-box in their promoter regions ( $h r p$ value $\geq 2500$ ).

(c) Venn diagram of downregulated genes identified by RNA-seq (in vitro) and BPGs (in silico).

\subsection{HrpL Is a Master Regulator of T3SS and Its Effectors in P. savastanoi pv. savastanoi}

The hrp/hrc cluster of Psv NCPPB 3335 is formed by 29 genes organized in five operons (Figure 5), four of which contain structural genes with roles in the Secretory system and one formed by $h r p R$ and $h r p S$, two regulatory elements that regulate the expression of $h r p L$. Besides these Structural and regulatory genes, Psv NCPPB 3335 encodes 31 T3Es in its genome $[44,46,47]$. Except for the operon formed by $h r p R / h r p S$, the remaining structural operons contained an hrp-box upstream of their first ORF, suggesting that gene expression is regulated by HrpL. In fact, the RNA-seq data showed that, except for $h r p K$ and $h r c S$, 
the expression of $h r p / h r c$ genes was downregulated in the $\Delta h r p L$ mutant compared with the wild-type Strain (Figure 5 and Table S7). Although the expression of $h r c S$, a member of the $h r p P$ operon, did not show a significant $q$ value $(0,921)$, its expression was also downregulated, with a fold change value $\left(\log _{2}\right)$ of -4.15 (Figure 5). However, unlike what was previously described for other strains of the P. syringae complex, hrpK was significantly overexpressed in the mutant strain compared with the wild-type (Figure 5 and Table S7). Besides $h r p K$, the first gene of the operon (Figure 5), the expression of $\operatorname{sch} A$ and the T3E hopA2 was also upregulated in the $\Delta h r p L$ mutant.

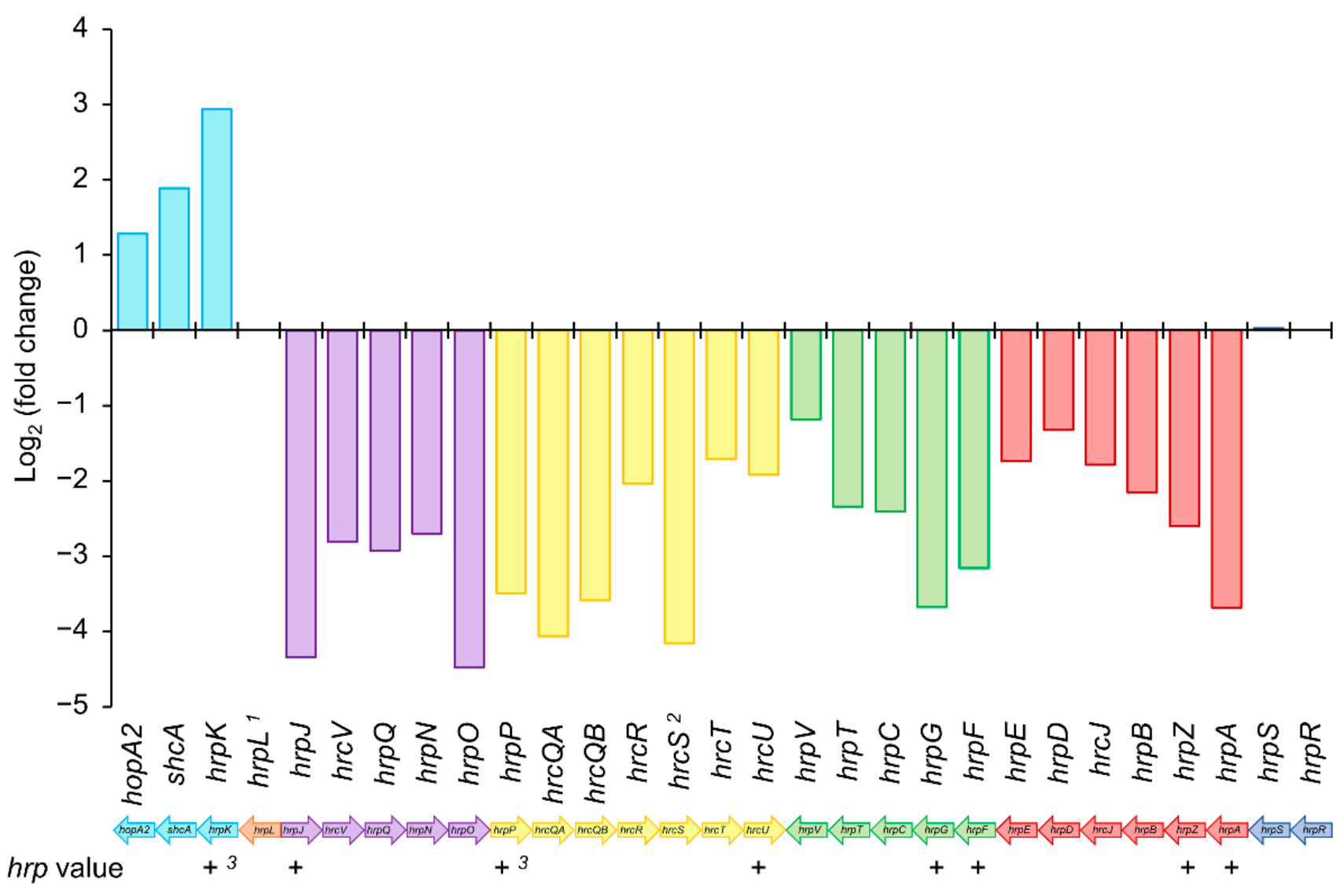

Figure 5. Regulation by HrpL of $h r p / h r c$ cluster in P. savastanoi pv. savastanoi NCPPB 3335. Colored bars indicate $\log _{2}$ (fold change) value obtained in RNA-seq analysis for wild-type Strain vs. its $\Delta h r p L$ mutant. Negative and positive values indicate genes repressed and overexpressed, respectively, in $\Delta h r p L$ mutant compared to wild-type Strain. ${ }^{1}$ Expression value obtained for $h r p L$ was zero in $\Delta h r p L$ mutant. ${ }^{2} q$ value $<0.05$ was not observed for $h r c S$ gene. + and - , presence or absence of $h r p$-box identified bioinformatically. ${ }^{3} h r p$-box manually identified. Genes (bars) with the Same color take part in the Same operon.

In addition to the Structural genes encoded in the $h r p / h r c$ cluster, RNA-seq analysis showed that the expression of five auxiliary genes of the T3SS, encoding two chaperones $(s h c V$ and $s h c F)$ and three helper proteins (hopAK1, hrpW1, and $h r p H)$, was repressed in the $\Delta h r p L$ mutant (Table 1). Out of these genes, $s h c F$ formed an operon with avrRpm2, a T3E whose expression was also downregulated in the $\Delta h r p L$ mutant compared with the wild-type Strain (Figure 6, Table S8). The bioinformatic prediction showed the presence of an $h r p$-box in three out of the five genes (hopAK1, shcV, and $s h c F$ ), and for the gene encoding the chaperone ShcM, which forms an operon with hopM1, a gene was also identified through RNA-seq analysis (Table 1). 
Table 1. Genes associated with T3SS under regulation of HrpL in P. savastanoi pv. savastanoi NCPPB 3335.

\begin{tabular}{|c|c|c|c|c|c|c|c|c|c|c|c|}
\hline \multirow[b]{2}{*}{$\begin{array}{l}\text { Accession } \\
\text { Number }^{\text {a }}\end{array}$} & \multirow[b]{2}{*}{ Gene } & \multirow[b]{2}{*}{$\mathbf{O}^{\mathrm{b}}$} & \multicolumn{2}{|c|}{ RNA-seq $^{c}$} & \multicolumn{7}{|c|}{ HrpL Dependence in other Pathovars ${ }^{e}$} \\
\hline & & & $q$ Value & $\begin{array}{c}\log _{2} \\
\text { (fc) }\end{array}$ & $\begin{array}{c}\text { hrp } \\
\text { Value } \\
\mathrm{d}\end{array}$ & Pto & Pph & Psy & Pla & Pja & Por \\
\hline \multicolumn{12}{|c|}{ Genes Associated with T3SS } \\
\hline PSA3335_RS07245 & hopAK1 & & 0.006 & -1.85 & 2741 & & & & & & \\
\hline PSA3335_RS10495 & hrpW1 & & 0.006 & -1.66 & nd & & & & & & \\
\hline PSA3335_RS10540 & hrpH & & 0.006 & -1.60 & nd & & & & & & \\
\hline PSA3335_RS10690 & $\operatorname{shc} A$ & 2 & 0.006 & 1.89 & & & & & & & \\
\hline PSA3335_RS15920 & $s h c V$ & & 0.006 & -3.14 & 2701 & & & & & & \\
\hline PSA3335_RS25240 & $s h c F$ & 1 & 0.006 & -1.33 & 2699 & & & & & & \\
\hline PSA3335_RS10520 & shcM & 1 & - & - & 2685 & & & & & & \\
\hline
\end{tabular}

a Accession number in NCBI (https:/ / www.ncbi.nlm.nih.gov/, accessed on 1 June 2021). ${ }^{\mathrm{b}}$ O, operon. Number indicates order of gene within the operon (from $5^{\prime}$ to $3^{\prime}$ ). ${ }^{c}$ Genes identified by RNA-seq. Significantly differentially expressed genes have $q$ values $<0.05$. Fold change (fc) refers to average expression rate obtained in $\Delta h r p L$ mutant relative to wild-type Strain in two biological replicates. Negative (red) and positive (green) $\log _{2}(\mathrm{fc}$ ) correspond to genes downregulated and upregulated, respectively, in $\Delta h r p L$ mutant relative to wild-type Strain. $\mathrm{d}$ Bioinformatic prediction of putative $h r p$-box upstream of start codon of genes encoded in P. savastanoi pv. savastanoi NCPPB 3335 genome ( $h r p$ value $\geq 2500$ ); nd, not detected. ${ }^{\text {e }}$ Red box, strains in which activation by HrpL of a homologous protein was identified by RNA-seq [48,49]. Pto, Pph, Psy, Pla, Pja, and Por: P. syringae pv. tomato DC3000, P. syringae pv. phaseolicola 1448A, P. syringae pv. syringae B728A, P. syringae pv. lachrymans 107, P. syringae pv. japonica MAFF 301072, and P. syringae pv. oryzae 1_6, respectively.

Among the 31 annotated T3Es in Psv NCPPB 3335 [44], RNA-seq analysis identified 12 effectors whose expression was downregulated (avrPto1, avrRpm2, hopAA1, hopAB1, hopAE1, hopAO1, hopAU1, hopAZ1, hopI1, hopM1, hopR1, and hopV1) and one (hopA2) whose expression was upregulated in the $\triangle h r p L$ mutant compared with the wild-type Strain (Figure 6a and Table S8). Among these 13 deregulated genes, two (avrPto1 and hopAO1) coincided with some of the eight genes whose HrpL dependency was demonstrated by RT-qPCR in P. savastanoi pv. savastanoi NCPPB 3335 [47,70,71]. The bioinformatic analysis predicted a total of 9 genes that contained an $h r p$-box and 11 genes that encoded proteins containing an $\mathrm{N}$-terminal translocation signal (Figure $6 \mathrm{~b}$ and Table S8). Among the effectors identified by the aforementioned methods, only avrPto1, avrRpm2, and hopAB1 were identified with all of them (Figure 6b). Interestingly, using both of these criteria (RNA-seq analysis and bioinformatic prediction), we identified a putative non-annotated T3E homologous to the XopAD effector from Xanthomonas, which is also encoded by $P$. syringae pv. phaseolicola 1448A and for which HrpL dependency has been demonstrated (Table S8) [72].

\subsection{HrpL Regulon of P. savastanoi pv. savastanoi Also Regulates Expression of Genes Unnrelated to T3SS}

In addition to genes related to the T3SS, genes encoding proteins annotated as hypothetical proteins, toxins, signaling proteins, and proteins related to secondary metabolites were also identified in the RNA-seq analysis (Table 2). Four out of the five genes encoding hypothetical proteins showed downregulated expression and only one was upregulated in the $\Delta h r p L$ mutant (Table 2). Among these five genes, the bioinformatic analysis revealed the existence of an $h r p$-box upstream of the HP02555 and HP29775 genes and a translocation signal in the protein encoded by the HP07405 gene. Interestingly, the first gene ( $h s v A$ ) of an operon related to the Synthesis of phevamine A, a toxin that can suppress the plant immune response [73], was identified by RNA-seq as part of the HrpL regulon of Psv (Table 2). The expression of $h s v A$ was downregulated in the $\Delta h r p L$ mutant compared with the wild-type Strain. Furthermore, genes encoding a TonB-dependent siderophore receptor (fecA), a hypothetical protein homologous to a N-acyl homoserine lactone Sintase (HP05360) and a FMN transferase $(a p b E)$, were identified by RNA-seq as part of the HrpL regulon of Psv NCPPB 3335 (Table 2). 
(a)

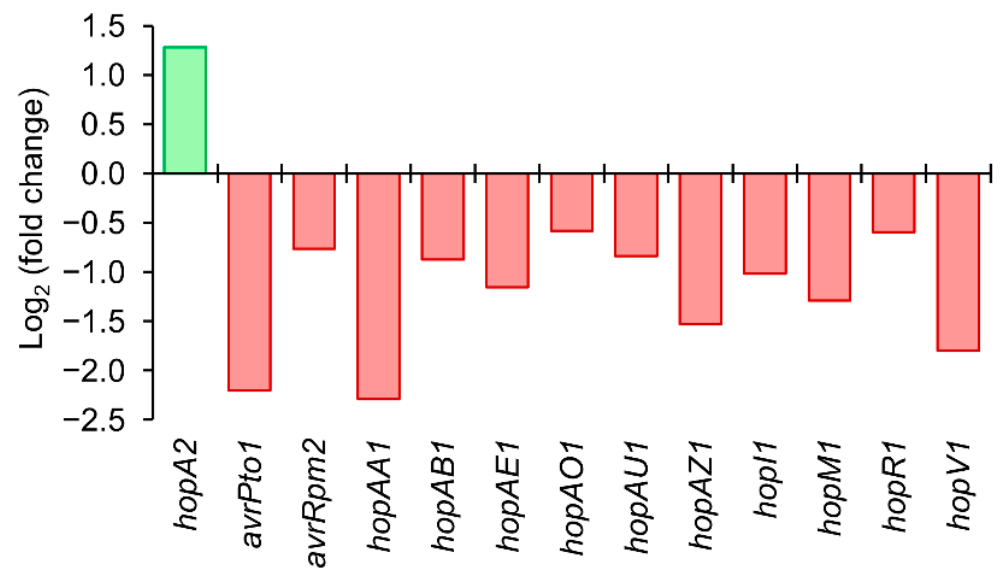

(b)

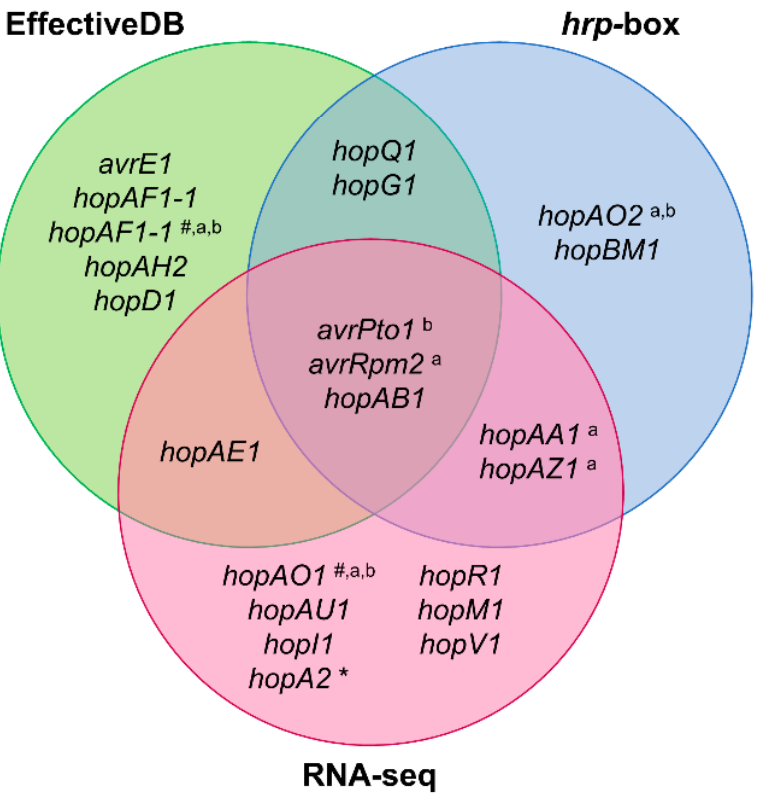

Figure 6. T3Es regulated by HrpL in P. savastanoi pv. savastanoi NCPPB 3335. (a) Graphical representation of $\log _{2}$ (fold change) values of T3E genes obtained by RNA-seq analysis of $\Delta h r p L$ mutant and wild-type Strain. Negative and positive values represent downregulation and upregulation of genes, respectively. (b) Venn diagram of T3E genes identified by RNA-seq analysis, bioinformatic prediction of $h r p$-box, and N-terminal T3SS targeting pattern (EffectiveDB). Diagram labeled "not detected" represents all T3E genes of Psv NCPPB 3335 that were not identified by the three methods. \# plasmidencoded genes; ${ }^{a}$ T3E genes of Psv NCPPB 3335 for which translocation through T3SS was experimentally demonstrated; b T3E genes for which dependence on HrpL was demonstrated by RT-qPCR in Psv NCPPB 3335 [47,70,71]. * HrpL represses expression of HopA2.

Although the number of genes identified by RNA-seq was not high, the bioinformatic analysis revealed 26 additional genes containing a predicted $h r p$-box (Table 3 ). The proteins encoded by all 26 predicted genes were classified into five categories: secondary metabolism, signaling, hypothetical proteins, transporters, and others. For the eight predicted genes encoding hypothetical proteins, their predicted secondary structures were compared with the Structures of other proteins included on the HHPred server [69]. However, matches with other proteins were not found. Among the hypothetical proteins, those encoded by PSA3335_RS11510 and PSA3335_RS10865 showed a translocation signal, suggesting that they could be putative T3Es. Among these 26 genes, four showed identity with genes whose dependence on $\mathrm{HrpL}$ was previously reported in strains belonging to the $P$. syringae complex (Table 3 ). 
Table 2. HrpL regulon proteins unrelated to T3SS and identified by RNA-seq in P. savastanoi pv. savastanoi NCPPB 3335.

\begin{tabular}{|c|c|c|c|c|c|c|c|c|c|c|c|c|c|c|c|}
\hline \multirow[t]{2}{*}{ Accession Number ${ }^{a}$} & \multirow{2}{*}{ Annotation } & \multirow{2}{*}{ Size (aa) } & \multicolumn{2}{|c|}{ Domains $^{b}$} & \multirow[t]{2}{*}{ Gene $^{c}$} & \multicolumn{2}{|c|}{ RNA-seq $^{\text {d }}$} & \multirow{2}{*}{$\begin{array}{c}\text { hrp } \\
\text { Value }\end{array}$} & \multirow{2}{*}{$\begin{array}{c}\text { Effective } \\
\text { DB }^{f}\end{array}$} & \multicolumn{6}{|c|}{$\begin{array}{l}\text { HrpL Dependence in other } \\
\text { Pathovars } g\end{array}$} \\
\hline & & & Pfam & HHPred & & $q$ Value & $\log _{2}(f c)$ & & & Pto & Pph & Psy & Pla & Pja & Por \\
\hline \multicolumn{16}{|c|}{ Hypothetical proteins } \\
\hline PSA3335_RS02555 & $\begin{array}{l}\text { Hypothetical } \\
\text { protein }\end{array}$ & 61 & - & 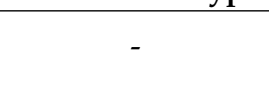 & НР02555 & 0.006 & -1.39 & 2789 & nd & & & & & & \\
\hline PSA3335_RS07405 & $\begin{array}{l}\text { Hypothetical } \\
\text { protein }\end{array}$ & 41 & - & - & HР07405 & 0.012 & $\#$ & nd & 0.9999 & & & & & & \\
\hline PSA3335_RS29775 & $\begin{array}{l}\text { Hypothetical } \\
\text { protein }\end{array}$ & 40 & - & - & HP29775 & 0.006 & -2.16 & 2785 & nd & & & & & & \\
\hline PSA3335_RS25230 & $\begin{array}{l}\text { Hypothetical } \\
\text { protein }\end{array}$ & 221 & - & - & HP25230 & 0.017 & -0.58 & nd & nd & & & & & & \\
\hline PSA3335_RS28495 & $\begin{array}{l}\text { Hypothetical } \\
\text { protein }\end{array}$ & 260 & - & - & HP28495 & 0.006 & 0.77 & nd & nd & & & & & & \\
\hline \multicolumn{16}{|c|}{ Toxins } \\
\hline PSA3335_RS07880 & Amidinotransferase & 366 & - & HsvA protein & $h s v A^{1}$ & 0.006 & -0.87 & nd & nd & & & & & & \\
\hline PSA3335_RS07885 & HPr kinase & 418 & - & - & $h s v B^{2}$ & & NS & nd & nd & & & & & & \\
\hline \multicolumn{16}{|c|}{ Signaling } \\
\hline PSA3335_RS09570 & $\begin{array}{l}\text { TonB-dependent } \\
\text { siderophore } \\
\text { receptor }\end{array}$ & 782 & $\begin{array}{l}\text { PF07660 } \\
\text { PF07715 } \\
\text { PF00593 }\end{array}$ & $\begin{array}{c}\text { Iron (III) dicitrate } \\
\text { transport protein } \\
\text { FecA }\end{array}$ & $f e c A$ & 0.006 & -0.62 & nd & nd & & & & & & \\
\hline PSA3335_RS05360 & $\begin{array}{l}\text { Hypothetical } \\
\text { protein }\end{array}$ & 212 & - & $\begin{array}{c}\text { N-acyl } \\
\text { homoserine } \\
\text { lactone Synthase }\end{array}$ & НР05360 & 0.006 & -1.34 & 2763 & nd & & & & & & \\
\hline \multicolumn{16}{|c|}{ Secondary metabolism } \\
\hline PSA3335_RS20310 & FMN transferase & 343 & PF02424 & FMN transferase & $a p b E$ & 0.017 & -0.63 & 2783 & nd & & & & & & \\
\hline
\end{tabular}

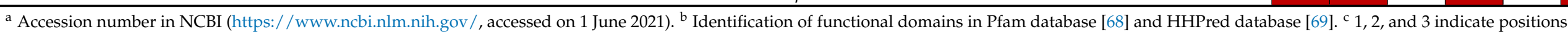

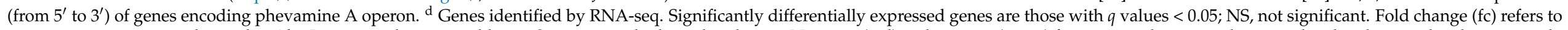

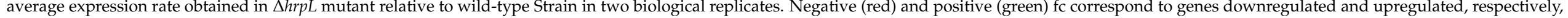

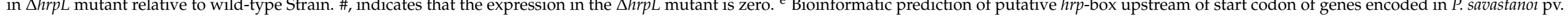

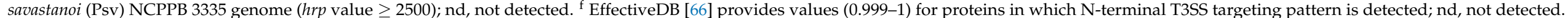

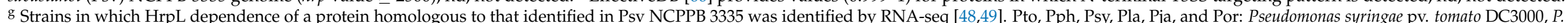
syringae pv. phaseolicola 1448A, P. syringae pv. syringae B728A, P. syringae pv. lachrymans 107, P. syringae pv. japonica MAFF 301072, and P. syringae pv. oryzae 1_6, respectively. 
Table 3. Bioinformatic prediction of putative hrp-box upstream of start codon of genes encoded in P. savastanoi pv. savastanoi NCPPB 3335 genome.

\begin{tabular}{|c|c|c|c|c|c|c|c|c|c|c|c|c|c|c|}
\hline \multirow{2}{*}{ Accession Number ${ }^{a}$} & \multirow{2}{*}{ Annotation } & \multirow{2}{*}{$\begin{array}{l}\text { Size } \\
\text { (aa) }\end{array}$} & \multirow{2}{*}{$\mathbf{O}^{b}$} & \multirow{2}{*}{ Place $^{b}$} & \multirow{2}{*}{$h r p$ Value $^{\mathrm{c}}$} & \multirow{2}{*}{ EffectiveDB $^{d}$} & \multirow{2}{*}{ Pfam $^{e}$} & \multirow{2}{*}{ HHPred $^{f}$} & \multicolumn{6}{|c|}{ HrpL Dependence in other Pathovars $g$} \\
\hline & & & & & & & & & Pto & Pph & Psy & Pla & Pja & Por \\
\hline \multicolumn{15}{|c|}{ Secondary metabolism } \\
\hline PSA3335_RS07710\# & Alcohol dehydrogenase & 85 & yes & 1 & 2718 & nd & PF08240 & - & & & & & & \\
\hline PSA3335_RS12335 & Alcohol dehydrogenase & 389 & yes & 2 & 2624 & nd & PF00465 & - & & & & & & \\
\hline PSA3335_RS26215 & $\begin{array}{l}\text { 1-acyl-sn-glycerol-3- } \\
\text { phosphate } \\
\text { acyltransferase }\end{array}$ & 270 & yes & 2 & 2586 & nd & PF01553 & - & & & & & & \\
\hline PSA3335_RS05405 & iaaLPsn & 395 & no & - & 2568 & nd & - & - & & & & & & \\
\hline PSA3335_RS27660 & $\begin{array}{c}\text { Fructose-1,6-bisphosphate } \\
\text { aldolase }\end{array}$ & 354 & no & - & 2539 & nd & PF01116 & - & & & & & & \\
\hline PSA3335_RS18565 & $\begin{array}{l}\text { Aminomethyltransferase } \\
\text { (soxA) }\end{array}$ & 968 & yes & 5 & 2511 & nd & $\begin{array}{l}\text { PF01571 } \\
\text { PF17806 } \\
\text { PF13510 } \\
\text { PF08669 } \\
\text { PF07992 }\end{array}$ & - & & & & & & \\
\hline PSA3335_RS18560 & $\begin{array}{c}\text { Sarcosine oxidase Subunit } \\
\text { delta }(\text { soxD) }\end{array}$ & 101 & yes & 4 & 2511 & nd & PF04267 & - & & & & & & \\
\hline \multicolumn{15}{|c|}{ Signaling } \\
\hline PSA3335_RS04530 & $\begin{array}{l}\text { TetR family transcriptional } \\
\text { regulator }\end{array}$ & 220 & yes & 1 & 2587 & nd & $\begin{array}{l}\text { PF08362 } \\
\text { PF00440 }\end{array}$ & - & & & & & & \\
\hline PSA3335_RS04245 & Transcriptional regulator & 80 & no & - & 2572 & nd & PF13560 & & & & & & & \\
\hline PSA3335_RS20160 & $\begin{array}{c}\text { Response regulator } \\
\text { transcription factor }(\operatorname{luxR})\end{array}$ & 222 & yes & 2 & 2570 & nd & $\begin{array}{l}\text { PF00072 } \\
\text { PF00196 }\end{array}$ & & & & & & & \\
\hline PSA3335_RS25950 & Response regulator & 121 & yes & 2 & 2504 & nd & PF00072 & & & & & & & \\
\hline PSA3335_RS07965 & $\begin{array}{l}\text { Chemotaxis response } \\
\text { regulator protein-glutamate } \\
\text { methylesterase }\end{array}$ & 358 & yes & 9 & 2500 & nd & $\begin{array}{l}\text { PF01339 } \\
\text { PF00072 }\end{array}$ & & & & & & & \\
\hline
\end{tabular}


Table 3. Cont.

\begin{tabular}{|c|c|c|c|c|c|c|c|c|c|c|c|c|c|c|}
\hline \multirow{2}{*}{ Accession Number ${ }^{a}$} & \multirow{2}{*}{ Annotation } & \multirow{2}{*}{$\begin{array}{l}\text { Size } \\
\text { (aa) }\end{array}$} & \multirow{2}{*}{$\mathbf{O}^{\mathbf{b}}$} & \multirow{2}{*}{ Place $^{b}$} & \multirow{2}{*}{$h r p$ Value $^{\mathrm{c}}$} & \multirow{2}{*}{ EffectiveDB $^{d}$} & \multirow{2}{*}{ Pfam ${ }^{e}$} & \multirow{2}{*}{ HHPred $^{\mathrm{f}}$} & \multicolumn{6}{|c|}{ HrpL Dependence in other Pathovars $g$} \\
\hline & & & & & & & & & Pto & Pph & Psy & Pla & Pja & Por \\
\hline \multicolumn{15}{|c|}{ Hypothetical proteins } \\
\hline PSA3335_RS00675 & Hypothetical protein & 224 & yes & 2 & 2580 & nd & - & $\begin{array}{l}\text { Haloacid } \\
\text { dehaloge- } \\
\text { nase }\end{array}$ & & & & & & \\
\hline PSA3335_RS11510 & Hypothetical protein & 289 & yes & 2 & 2577 & 0.9994 & PF01904 & - & & & & & & \\
\hline PSA3335_RS23410\# & Hypothetical protein & 48 & yes & 2 & 2567 & nd & PF07551 & - & & & & & & \\
\hline PSA3335_RS13135 & Hypothetical protein & 79 & no & - & 2539 & nd & - & - & & & & & & \\
\hline PSA3335_RS26045 & Hypothetical protein & 107 & yes & 5 & 2531 & nd & PF11872 & - & & & & & & \\
\hline PSA3335_RS06145 & Hypothetical protein & 166 & yes & 2 & 2518 & nd & PF14113 & $\begin{array}{c}\text { T6SS } \\
\text { effector } \\
\text { Tae4 }\end{array}$ & & & & & & \\
\hline PSA3335_RS10865 & Hypothetical protein & 290 & yes & 1 & 2517 & 0.9998 & - & $\begin{array}{l}\text { T7 capsid } \\
\text { protein }\end{array}$ & & & & & & \\
\hline \multicolumn{15}{|l|}{ Transporters } \\
\hline PSA3335_RS07870 & MFS transporter & 395 & no & - & 2560 & nd & PF07690 & & & & & & & \\
\hline PSA3335_RS20980 & MFS transporter & 399 & no & - & 2523 & nd & PF07690 & & & & & & & \\
\hline \multicolumn{15}{|l|}{ Others } \\
\hline PSA3335_RS15760 & $\begin{array}{l}\text { Peptidyl-propyl cis-trans } \\
\text { isomerase }\end{array}$ & 91 & no & - & 2506 & nd & PF00639 & & & & & & & \\
\hline PSA3335_RS01395 & $\begin{array}{c}\text { DUF2628 } \\
\text { domain-containing protein }\end{array}$ & 141 & no & - & 2501 & nd & PF10947 & & & & & & & \\
\hline
\end{tabular}

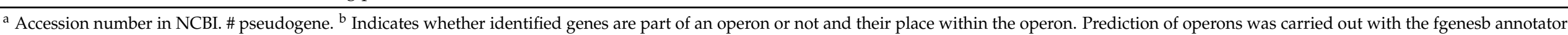

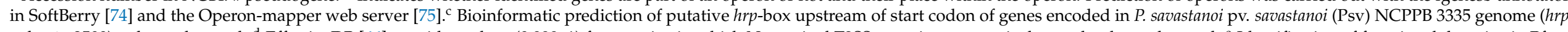

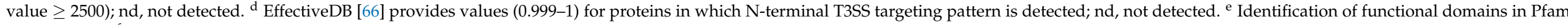

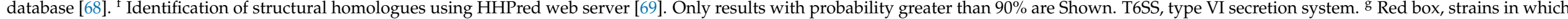

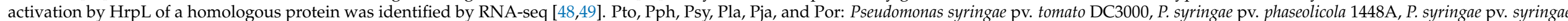
B728A, P. syringae pv. lachrymans 107, P. syringae pv. japonica MAFF 301072, and P. syringae pv. oryzae 1_6, respectively. 


\section{Discussion}

We evaluated the importance of HrpL, an essential transcriptional regulator of virulence functions, in the virulence of five pathovars of P. savastanoi (Psv, Psn, Psf, Psr, and Psm) that cause disease in woody hosts (olive, oleander, ash, broom, and dipladenia). Given the inability of some P. savastanoi strains to induce HR in tobacco plants, the capacity to induce $\mathrm{HR}$ in a non-host plant was assessed in tobacco and tomato plants for all the Strains and their corresponding $\Delta h r p L$ mutants (Figure 1). The Psn Psn 23 strain was previously described to induce HR in tobacco leaves, although the assay was performed in the Burley White cultivar [40], a tobacco cultivar different from that used in this work (Newdel). It is well known that the repertoire of bacterial T3Es, as well as the repertoire of plant resistance genes, can vary among bacterial strains or cultivars, thus conditioning the induction of a characteristic HR [76,77]. Furthermore, the characterization of strains Psn Psn 23 and Psm Ph3 shows that they contain a truncated version of avrPto1, which encodes a shorter version of the effector with a C-terminal deletion $[39,44]$. In this sense, it has been described that point mutations occurring at the C-terminal of AvrPto1 prevent HR formation in tobacco but not in tomato leaves, indicating that this part of the effector could participate in its recognition by the plant resistance protein [78]. During the last decade, it has been reported that bacterial species of the $P$. syringae complex can naturally lack the $\mathrm{hrp} / \mathrm{hrc}$ cluster, making them unable to induce HR in non-host plants or compromising their ability to cause disease in their respective hosts [19-21]. Genomic analysis carried out for Psv NCPPB 3335, Psn Psn23, Psm Ph3, Psf NCPPB 1006, and Psr CECT 4861 confirmed that all of these Strains contain a canonical hrp/hrc cluster [39,44], which allows them to cause disease Symptoms in their respective woody hosts (Figure 2). In the P. syringae complex, the role of HrpL as a global regulator of virulence has been mainly studied in pathogenic bacteria affecting herbaceous plants [48,49,79-81]. Our results demonstrate that HrpL is fully required for symptom development in P. savastanoi pathovars that cause disease in woody hosts (Figure 2).

The HrpL regulon of $P$. syringae strains, which affect herbaceous plants, has been widely studied using high-throughput sequencing and/or computational analysis [48,49,79-81]. In our work, using a combination of both strategies, we identified 53 deregulated genes and 50 candidate genes containing a putative $h r p$-box (Figure 3 and Table 3). Out of the 53 genes identified through RNA-seq analysis, 49 were downregulated compared with the wildtype Strain (Figure 3). Analysis carried out with six isolates of P. syringae (pv. phaseolicola, pv. lachrymans, pv. syringae, pv. japonica, and pv. tomato) showed that genes differentially expressed across the Strains were mostly upregulated [48]. However, these transcriptomic analyses were performed with mutants transformed with the native $h r p L$ gene cloned downstream of an arabinose-inducible promoter. By contrast, our RNA-seq data resulted from a $\Delta h r p L$ mutant in which the $h r p L$ locus was replaced, thus representing the opposite Situation reported by Mucyn and associates with overexpressing P. syringae strains. In agreement with previous data $[48,49]$, most of the genes identified in our RNA-seq analysis, 44 out of the 53 deregulated genes, were annotated as T3SS components (30 genes) or annotated T3Es (14 genes) (Figure 4), confirming that HrpL mainly regulates the T3SS and its effectors. Unexpectedly, $h r c S$ and $h r p K$ were two unique genes belonging to the $h r p / h r c$ cluster that were not significantly deregulated in the Psv $\Delta h r p L$ mutant. Regarding hrcS, while the $\log _{2}$ (fold change) value for this gene was about -4.15 (Table S7), suggesting clear repression in the $\Delta h r p L$ mutant, the $q$ value was greater than 0.05 , indicating a nonsignificant change. However, the fact that $h r c S$ occupies the fifth position in an operon (Figure 5), where all of the upstream ( $h r p P, h r c Q A, h r c Q B$, and $h r c R$ ) and downstream ( $h r c T$ and $\mathrm{hrcl}$ ) genes were Significantly repressed, would suggest that differences in transcript abundance across the biological replicates might explain the nonsignificant differences observed for this gene. In relation to $h r p K$, it was previously reported that this gene is activated by HrpL in P. syringae strains [48,49]. However, our transcriptomic analysis shows that the $h r p K$ gene was significantly upregulated in the $\Delta h r p L$ mutant compared with its wild-type Strain (Table S7). In P. syringae pv. tomato (Pto) DC3000, it has been 
described that HrpK is translocated extracellularly through the T3SS, and is required for symptom development and bacterial multiplication [82]. Furthermore, complementation assays for the hrpK mutants showed that HrpK does not function inside the plant cells, which would suggest a putative role for $\mathrm{HrpK}$ as a T3E translocator located at the plant membrane [82]. In Pto DC3000, hrpK is the first gene of an operon together with hopB1 [83]. However, in Psv NCPPB 3335, this operon is completed by shcA (PSA3335_RS10690) and hopA2 (hopPsyB; PSA3335_RS10695), the Same operon organization described in P. syringae pv. syringae 61 [83]. In accordance with the expression data obtained for $h r p K$, the expression of $s h c A$ and hopA2 was significantly upregulated in the $\Delta h r p L$ mutant compared with the wild-type Strain (Tables 1, S7 and S8). This result suggests that this operon could be repressed, directly or indirectly, by the transcription factor HrpL.

The genomic analysis of Psv NCPPB 3335 revealed that this pathogenic bacterium contains a total of 31 T3Es encoded in its genome [44]. In this study, we identified a total of 16 genes as part of the HrpL regulon, 7 genes identified by RNA-seq, 4 genes predicted bioinformatically, and 5 genes identified by both approaches (Figure 6 and Table S8). Of special interest was the identification of the pseudogene PSA3335_RS02560, which encodes a protein homologous to XopAD, a T3E from Xanthomonas [84-86]. Strikingly, in the genome of Psv NCPPB 3335, this gene appears to be Separated into two ORFs, the pseudogenes PSA3335_RS02560 and PSA3335_RS02565. However, even when both pseudogenes encode proteins that contain the characteristic SKWP repetitions [87], only the expression of PSA3335_RS02560 was found to be repressed in the RNA-seq analysis (Table S8). The fact that PSA3335_RS02560 contains an hrp-box within its promoter, as well as the existence of a type III translocation signal at the N-terminal of the protein sequence, suggest that PSA3335_RS02560 and its encoded protein could be a novel T3E acquired by Psv NCPPB 3335 (Table S8). The PSA3335_RS02560 gene is homologous to the PSPPH_1525 gene from Pseudomonas syringae pv. phaseolicola 1448A, whose expression has been reported to be regulated by HrpL and HrpS [72]. Demonstrating that PSA3335_RS02560 encodes a novel functional T3E in Psv NCPPB 3335 would require additional translocation assays with the protein effector.

An additional goal of work aimed at characterizing the HrpL regulon has been to identify genes, or $h r p$-boxes upstream of the genes, encoding potential virulence factors that are not related to the T3SS $[48,49,79,88]$. In this study, we identified a total of 34 potential genes whose expression is potentially influenced by HrpL that were not annotated as structural, auxiliary, or functional elements of the T3SS (Figure 4). As previously described, most of these nonrelated T3SS genes were annotated as hypothetical proteins, secondary metabolism, signaling, or toxins (Figure 4 and Tables 2 and 3). Included in the Signaling category, we identified two genes, PSA3335_RS09570 and PSA3335_RS05360, whose expression is regulated by HrpL. The former encodes a TonB-dependent siderophore receptor (FecA) protein (Table 2), an outer membrane transporter involved in citrate-mediated iron import in bacteria $[89,90]$. The analysis of iron-deficient mutants in P. syringae pv. tomato DC3000 suggests that, in contrast to mammalian pathosystems, siderophores may play a more Specialized role in iron nutrition, growth, and virulence in plant pathogenic bacteria during host colonization [89]. The latter gene, PSA3335_RS05360, was characterized as encoding a hypothetical protein homologous to $\mathrm{N}$-acyl homoserine lactone (AHL) synthase (Table 2). Broadly speaking, AHL is a signaling molecule involved in bacterial quorum sensing (QS), a relevant interbacterial communication system used to detect and respond to cell population density by gene regulation [91-93]. In previous work, it was reported that Psv and Erwinia toletana share QS signals and cooperate with each other, causing more Severe Symptoms in olive tree knots [94]. The existence of AHL synthase regulated by HrpL suggests a connection between the T3SS and the low bacterial cell density that exists during the first stages of host colonization.

Bacterial phytotoxins are widely distributed among all the major genera of plant pathogenic bacteria and are considered among the most important virulence factors in symptoms of disease $[95,96]$. In P. syringae, it was previously reported that genes encoding 
enzymes that participate in the Synthesis of coronatine and siringomycin are regulated by HrpL [65,97]. A similar HrpL dependency was observed for the hrp PAI of E. amylovora, which encodes the proteins required for the Synthesis of a putative phaseolotoxin-like phytotoxin [98]. Interestingly, as part of the Psv NCPPB 3335 HrpL regulon, we identified the $h s v A$ gene, whose expression was downregulated in the $\Delta h r p L$ mutant compared with the wild-type Strain (Table 2). This gene occupies the first position of the hsv operon ( $h s v A, h s v B$, and $h s v C$ ), a group of genes involved in synthesizing phevamine A, a small molecule classified as a toxin that suppresses the plant immune response during P. syringae infection [73]. It has also been reported that the expression of the hsv $A$ operon in $E$. amylovora depends on the HrpL regulator and is required for full virulence in apples [98]. Therefore, characterizing this operon in Psv NCPPB 3335, as well as other P. savastanoi strains, would contribute to a better understanding of its role in the virulence of plant pathogenic bacteria infecting woody hosts.

To summarize, high-throughput transcriptome Sequencing (RNA-seq) combined with the bioinformatic analysis of sequences containing an hrp-box allowed us to characterize the HrpL regulon of P. savastanoi pv. savastanoi NCPPB 3335. Although most of the identified predicted genes are related to structural or auxiliary functions of the T3SS, the combination of these two experimental approaches showed some potential genes, whose regulation is controlled by HrpL, that could be involved in the virulence of this pathogenic bacterium of woody hosts. Of particular interest was the detection of the $h s v A$ gene, which occupies the first position of an operon dedicated to the Synthesis of phevamine A, a phytotoxic molecule that participates in the Suppression of the plant immune response. The results obtained in this work suggest that HrpL not only orchestrates the expression of genes related to the T3SS but also genes that encode potential virulence factors required for the virulence of $P$. savastanoi in both host and non-host plants.

Supplementary Materials: The following are available online at https:/ / www.mdpi.com/article/10 .3390 / microorganisms9071447/s1. Figure S1: HrpL-dependent expression of HrpL regulon genes by RT-qPCR. Figure S2: Gene expression analysis of biological replicates used in RNA-seq study. Table S1: Strains used in this study. Table S2: Plasmids used in this study. Table S3: List and application of primers used in this work. Table S4: Reads obtained in RNA-seq. Table S5: Summary of Illumina RNA-seq data. Table S6: Genes shared by in vitro and in silico analysis. Table S7: Structural genes of T3SS and genes associated with T3SS under regulation of HrpL in P. savastanoi pv. savastanoi NCPPB 3335. Table S8: T3E genes under regulation of HrpL in P. savastanoi pv. savastanoi NCPPB 3335.

Author Contributions: Conceptualization, L.R.-M., and C.R.; funding acquisition and project administration, C.R.; supervision, L.R.-M., and C.R.; methodology and experiments, A.M.-P.; bioinformatic analysis, A.M.-P., L.R.-M., and C.R.; data curation A.M.-P., L.R.-M., and C.R.; L.R.-M., and C.R. drafted the manuscript with contribution from A.M.-P.; preparation of figures, A.M.-P., L.R.-M., and C.R.; preparation of tables, A.M.-P., L.R.-M., and C.R. All authors have read and agreed to the published version of the manuscript.

Funding: This research was funded by the Ministerio de Ciencia, Innovación y Universidades (Spain), cofinanced by the Fondo Europeo de Desarrollo Regional (FEDER), grant number AGL2017-83368-C2-1-R. A.M.-P. was supported by grant FPI/BES-2015-074847.

Institutional Review Board Statement: Not applicable.

Informed Consent Statement: Not applicable.

Data Availability Statement: The names of the repository/repositories and accession number(s) can be found in the paper and Supplementary Materials.

Acknowledgments: We thank J. Gómez-Maldonado, R. Bautista-Moreno, and L. Díaz for help with bioinformatic pipelines; and P. García-Vallejo for technical assistance.

Conflicts of Interest: The authors declare no conflict of interest. The funders had no role in the design of the Study; in the collection, analysis, or interpretation of data; in the writing of the manuscript; or in the decision to publish the results. 


\section{References}

1. Lee, C.A. Type III secretion systems: Machines to deliver bacterial proteins into eukaryotic cells? Trends Microbiol. 1997, 5, 148-156. [CrossRef]

2. Hueck, C.J. Type III protein secretion systems in bacterial pathogens of animals and plants. Microbiol. Mol. Biol. Rev. 1998, 62, 379-433. [CrossRef] [PubMed]

3. Kubori, T.; Matsushima, Y.; Nakamura, D.; Uralil, J.; Lara-Tejero, M.; Sukhan, A.; Galán, J.E.; Aizawa, S.-I. Supramolecular structure of the Salmonella typhimurium type III protein secretion system. Science 1998, 280, 602-605. [CrossRef] [PubMed]

4. Galan, J.E.; Collmer, A. Type III secretion machines: Bacterial devices for protein delivery into host cells. Science 1999, 284, 1322-1328. [CrossRef] [PubMed]

5. Jin, Q.; He, S.-Y. Role of the Hrp pilus in type III protein secretion in Pseudomonas syringae. Science 2001, 294, 2556-2558. [CrossRef]

6. Büttner, D. Behind the lines-actions of bacterial type III effector proteins in plant cells. FEMS Microbiol. Rev. 2016, 40, 894-937. [CrossRef]

7. Schulmeyer, K.H.; Yahr, T.L. Post-transcriptional regulation of type III secretion in plant and animal pathogens. Curr. Opin. Microbiol. 2017, 36, 30-36. [CrossRef]

8. Deng, W.; Marshall, N.C.; Rowland, J.L.; McCoy, J.M.; Worrall, L.J.; Santos, A.S.; Strynadka, N.C.J.; Finlay, B.B. Assembly, structure, function and regulation of type III secretion systems. Nat. Rev. Microbiol. 2017, 15, 323-337. [CrossRef]

9. Cornelis, G.R.; Van Gijsegem, F. Assembly and function of type III secretory systems. Annu. Rev. Microbiol. 2000, 54, 735-774. [CrossRef]

10. Zhou, J.-M.; Chai, J. Plant pathogenic bacterial type III effectors subdue host responses. Curr. Opin. Microbiol. 2008, 11, 179-185. [CrossRef]

11. Büttner, D. Protein export according to schedule: Architecture, assembly, and regulation of type III secretion systems from plantand animal-pathogenic bacteria. Microbiol. Mol. Biol. Rev. 2012, 76, 262-310. [CrossRef]

12. Feng, F.; Zhou, J.-M. Plant-bacterial pathogen interactions mediated by type III effectors. Curr. Opin. Plant Biol. 2012, 15, 469-476. [CrossRef]

13. Raymond, B.; Young, J.C.; Pallett, M.; Endres, R.G.; Clements, A.; Frankel, G. Subversion of trafficking, apoptosis, and innate immunity by type III secretion system effectors. Trends Microbiol. 2013, 21, 430-441. [CrossRef] [PubMed]

14. Mansfield, J.; Genin, S.; Magori, S.; Citovsky, V.; Sriariyanum, M.; Ronald, P.; Dow, M.A.X.; Verdier, V.; Beer, S.V.; Machado, M.A.; et al. Top 10 plant pathogenic bacteria in molecular plant pathology. Mol. Plant Pathol. 2012, 13, 614-629. [CrossRef]

15. Xin, X.-F.; Kvitko, B.; He, S.Y. Pseudomonas syringae: What it takes to be a pathogen. Nat. Rev. Microbiol. 2018, 16, 316-328. [CrossRef] [PubMed]

16. Berge, O.; Monteil, C.L.; Bartoli, C.; Chandeysson, C.; Guilbaud, C.; Sands, D.C. A user's guide to a data base of the diversity of Pseudomonas syringae and its application to classifying strains in this phylogenetic complex. PLoS ONE 2014, 9, e105547. [CrossRef]

17. Gomila, M.; Busquets, A.; Mulet, M.; García-Valdés, E.; Lalucat, J. Clarification of taxonomic status within the Pseudomonas syringae species group based on a phylogenomic analysis. Front. Microbiol. 2017, 8. [CrossRef] [PubMed]

18. Bull, C.T.; Koike, S.T. Practical benefits of knowing the enemy: Modern molecular tools for diagnosing the etiology of bacterial diseases and understanding the taxonomy and diversity of plant-pathogenic bacteria. Annu. Rev. Phytopathol. 2015, 53, 157-180. [CrossRef] [PubMed]

19. Mohr, T.J.; Liu, H.; Yan, S.; Morris, C.E.; Castillo, J.A.; Jelenska, J.; Vinatzer, B.A. Naturally occurring nonpathogenic isolates of the plant pathogen Pseudomonas syringae lack a type III secretion system and effector gene orthologues. J. Bacteriol. 2008, 190, 2858-2870. [CrossRef]

20. Clarke, C.R.; Cai, R.; Studholme, D.J.; Guttman, D.S.; Vinatzer, B.A. Pseudomonas syringae strains naturally lacking the classical P. syringae $\mathrm{hrp} / \mathrm{hrc}$ locus are common leaf colonizers equipped with an atypical type III secretion system. Mol. Plant-Microbe Interact. 2010, 23, 198-210. [CrossRef]

21. Diallo, M.D.; Monteil, C.L.; Vinatzer, B.A.; Clarke, C.R.; Glaux, C.; Guilbaud, C.; Desbiez, C.; Morris, C.E. Pseudomonas syringae naturally lacking the canonical type III secretion system are ubiquitous in nonagricultural habitats, are phylogenetically diverse and can be pathogenic. ISME J. 2012, 6, 1325-1335. [CrossRef]

22. Lindgren, P.B.; Panopoulos, N.J.; Staskawicz, B.J.; Dahlbeck, D. Genes required for pathogenicity and hypersensitivity are conserved and interchangeable among pathovars of Pseudomonas syringae. Mol. Gen. Genet. 1988, 211, 499-506. [CrossRef]

23. Lindgren, P.B.; Peet, R.C.; Panopoulos, N.J. Gene cluster of Pseudomonas syringae pv. "phaseolicola" controls pathogenicity of bean plants and hypersensitivity of nonhost plants. J. Bacteriol. 1986, 168, 512-522. [CrossRef]

24. Alfano, J.R.; Charkowski, A.O.; Deng, W.-L.; Badel, J.L.; Petnicki-Ocwieja, T.; van Dijk, K.; Collmer, A. The Pseudomonas syringae Hrp pathogenicity island has a tripartite mosaic structure composed of a cluster of type III secretion genes bounded by exchangeable effector and conserved effector loci that contribute to parasitic fitness and pathogenicity in plants. Proc. Natl. Acad. Sci. USA 2000, 97, 4856-4861. [CrossRef] [PubMed]

25. Collmer, A.; Badel, J.L.; Charkowski, A.O.; Deng, W.L.; Fouts, D.E.; Ramos, A.R.; Rehm, A.H.; Anderson, D.M.; Schneewind, O.; van Dijk, K.; et al. Pseudomonas syringae Hrp type III secretion system and effector proteins. Proc. Natl. Acad. Sci. USA 2000, 97, 8770-8777. [CrossRef] [PubMed]

26. Jones, J.D.; Dangl, J.L. The plant immune System. Nature 2006, 444, 323-329. [CrossRef] [PubMed] 
27. Fouts, D.E.; Badel, J.L.; Ramos, A.R.; Rapp, R.A.; Collmer, A. A Pseudomonas syringae pv. tomato DC3000 Hrp (type III secretion) deletion mutant expressing the Hrp system of bean pathogen P. syringae pv. syringae 61 retains normal host specificity for tomato. Mol. Plant-Microbe Interact. 2003, 16, 43-52. [CrossRef] [PubMed]

28. Lindeberg, M.; Cunnac, S.; Collmer, A. The evolution of Pseudomonas syringae host specificity and type III effector repertoires. Mol. Plant Pathol. 2009, 10, 767-775. [CrossRef] [PubMed]

29. Baltrus, D.A.; Nishimura, M.T.; Romanchuk, A.; Chang, J.H.; Mukhtar, M.S.; Cherkis, K. Dynamic evolution of pathogenicity revealed by sequencing and comparative genomics of 19 Pseudomonas syringae isolates. PLoS Pathog. 2011, 7, e1002132. [CrossRef]

30. Xiao, Y.; Hutcheson, S.W. A single promoter sequence recognized by a newly identified alternate Sigma factor directs expression of pathogenicity and host range determinants in Pseudomonas syringae. J. Bacteriol. 1994, 176, 3089-3091. [CrossRef]

31. Hendrickson, E.L.; Guevera, P.; Ausubel, F.M. The alternative Sigma factor RpoN is required for hrp activity in Pseudomonas syringae pv. maculicola and acts at the level of hrpL transcription. J. Bacteriol. 2000, 182, 3508-3516. [CrossRef] [PubMed]

32. Hutcheson, S.W.; Bretz, J.; Sussan, T.; Jin, S.; Pak, K. Enhancer-binding proteins HrpR and HrpS interact to regulate hrp-encoded type III protein secretion in Pseudomonas syringae strains. J. Bacteriol. 2001, 183, 5589-5598. [CrossRef]

33. Xie, Y.; Shao, X.; Deng, X. Regulation of type III secretion system in Pseudomonas syringae. Environ. Microbiol. 2019, 21, 4465-4477. [CrossRef] [PubMed]

34. Waite, C.; Schumacher, J.; Jovanovic, M.; Bennett, M.; Buck, M. Negative autogenous control of the master type III secretion system regulator HrpL in Pseudomonas syringae. mBio 2017, 8, e2273-16. [CrossRef]

35. Wang, T.; Cai, Z.; Shao, X.; Zhang, W.; Xie, Y.; Zhang, Y.; Hua, C.; Schuster, S.C.; Yang, L.; Deng, X. Pleiotropic effects of c-di-GMP content in Pseudomonas syringae. Appl. Environ. Microbiol. 2019, 85, e00152-19. [CrossRef]

36. Rahme, L.G.; Mindrinos, M.N.; Panopoulos, N.J. Plant and environmental sensory signals control the expression of $h r p$ genes in Pseudomonas syringae pv. phaseolicola. J. Bacteriol. 1992, 174, 3499-3507. [CrossRef]

37. Caballo-Ponce, E.; Murillo, J.; Martínez-Gil, M.; Moreno-Pérez, A.; Pintado, A.; Ramos, C. Knots untie: Molecular determinants involved in knot formation induced by Pseudomonas savastanoi in woody hosts. Front. Plant Sci. 2017, 8, 1089. [CrossRef]

38. Dillon, M.M.; Thakur, S.; Almeida, R.N.D.; Wang, P.W.; Weir, B.S.; Guttman, D.S. Recombination of ecologically and evolutionarily significant loci maintains genetic cohesion in the Pseudomonas syringae species complex. Genome Biol. 2019, 20, 3. [CrossRef] [PubMed]

39. Caballo-Ponce, E.; Pintado, A.; Moreno-Pérez, A.; Murillo, J.; Smalla, K.; Ramos, C. Pseudomonas savastanoi pv. mandevillae pv. nov., a clonal pathogen causing an emerging, devastating disease of the ornamental plant Mandevilla spp. Phytopathology 2021. [CrossRef]

40. Cerboneschi, M.; Decorosi, F.; Biancalani, C.; Ortenzi, M.V.; Macconi, S.; Giovannetti, L.; Viti, C.; Campanella, B.; Onor, M.; Bramanti, E.; et al. Indole-3-acetic acid in plant-pathogen interactions: A key molecule for in planta bacterial virulence and fitness. Res. Microbiol. 2016, 167, 774-787. [CrossRef] [PubMed]

41. Matas, I.M.; Lambertsen, L.; Rodríguez-Moreno, L.; Ramos, C. Identification of novel virulence genes and metabolic pathways required for full fitness of Pseudomonas savastanoi pv. savastanoi in olive (Olea europaea) knots. New Phytol. 2012, 196, 1182-1196. [CrossRef]

42. Sisto, A.; Cipriani, M.G.; Morea, M. Knot formation caused by Pseudomonas syringae subsp. savastanoi on olive plants is hrp-dependent. Phytopathology 2004, 94, 484-489. [CrossRef] [PubMed]

43. Pérez-Martínez, I.; Rodríguez-Moreno, L.; Lambertsen, L.; Matas, I.M.; Murillo, J.; Tegli, S.; Jiménez, A.J.; Ramos, C. Fate of a Pseudomonas savastanoi pv. savastanoi type III secretion system mutant in olive plants (Olea europaea L.). Appl. Environ. Microbiol. 2010, 76, 3611-3619. [CrossRef] [PubMed]

44. Moreno-Pérez, A.; Pintado, A.; Murillo, J.; Caballo-Ponce, E.; Tegli, S.; Moretti, C.; Rodríguez-Palenzuela, P.; Ramos, C. Host range determinants of Pseudomonas savastanoi pathovars of woody hosts revealed by comparative genomics and cross-pathogenicity tests. Front. Plant Sci. 2020, 11, 973. [CrossRef] [PubMed]

45. Tegli, S.; Gori, A.; Cerboneschi, M.; Cipriani, M.G.; Sisto, A. Type three Secretion system in Pseudomonas savastanoi pathovars: Does timing matter? Genes 2011, 2, 957-979. [CrossRef] [PubMed]

46. Rodríguez-Palenzuela, P.; Matas, I.M.; Murillo, J.; López-Solanilla, E.; Bardaji, L.; Pérez-Martínez, I.; Rodríguez-Moskera, M.E.; Penyalver, R.; López, M.M.; Quesada, J.M.; et al. Annotation and overview of the Pseudomonas savastanoi pv. savastanoi NCPPB 3335 draft genome reveals the virulence gene complement of a tumour-inducing pathogen of woody hosts. Environ. Microbiol. 2010, 12, 1604-1620. [CrossRef] [PubMed]

47. Matas, I.M.; Castañeda-Ojeda, M.P.; Aragón, I.M.; Antúnez-Lamas, M.; Murillo, J.; Rodríguez-Palenzuela, P.; López-Solanilla, E.; Ramos, C. Translocation and functional analysis of Pseudomonas savastanoi pv. savastanoi NCPPB 3335 type III secretion system effectors reveals two novel effector families of the Pseudomonas syringae complex. Mol. Plant-Microbe Interact. 2014, 27, 424-436. [CrossRef]

48. Mucyn, T.S.; Yourstone, S.; Lind, A.L.; Biswas, S.; Nishimura, M.T.; Baltrus, D.A.; Cumbie, J.S.; Chang, J.H.; Jones, C.D.; Dangl, J.L.; et al. Variable Suites of non-effector genes are co-regulated in the type III secretion virulence regulon across the Pseudomonas syringae phylogeny. PLoS Pathog. 2014, 10, e1003807. [CrossRef]

49. Lam, H.N.; Chakravarthy, S.; Wei, H.L.; BuiNguyen, H.; Stodghill, P.V.; Collmer, A. Global analysis of the HrpL regulon in the plant pathogen Pseudomonas syringae pv. tomato DC3000 reveals new regulon members with diverse functions. PLoS ONE 2014, 9, e106115. [CrossRef] 
50. Bardaji, L.; Perez-Martinez, I.; Rodriguez-Moreno, L.; Rodriguez-Palenzuela, P.; Sundin, G.W.; Ramos, C.; Murillo, J. Sequence and role in virulence of the three plasmid complement of the model tumor-inducing bacterium Pseudomonas savastanoi pv. savastanoi NCPPB 3335. PLoS ONE 2011, 6, e25705. [CrossRef]

51. Bertani, G. Studies on lysogenesis. I. The mode of phage liberation by lysogenic Escherichia coli. J. Bacteriol. 1951, 62, 293-300. [CrossRef]

52. King, E.O.; Ward, M.K.; Raney, D.E. Two simple media for the demonstration of pyocyanin and fluorescin. J. Lab. Clin. Med. 1954, 44, 301-307. [CrossRef] [PubMed]

53. Hanahan, D. Studies on transformation of Escherichia coli with plasmids. J. Mol. Biol. 1983, 166, 557-580. [CrossRef]

54. Pérez-Martínez, I.; Rodríguez-Moreno, L.; Matas, I.M.; Ramos, C. Strain selection and improvement of gene transfer for genetic manipulation of Pseudomonas savastanoi isolated from olive knots. Res. Microbiol. 2007, 158, 60-69. [CrossRef]

55. Zumaquero, A.; Macho, A.P.; Rufian, J.S.; Beuzon, C.R. Analysis of the role of the type III effector inventory of Pseudomonas syringae pv. phaseolicola 1448a in interaction with the plant. J. Bacteriol. 2010, 192. [CrossRef] [PubMed]

56. Huynh, T.; Dahlbeck, D.; Staskawicz, B. Bacterial blight of soybean: Regulation of a pathogen gene determining host cultivar specificity. Science 1989, 245, 1374-1377. [CrossRef]

57. Langmead, B.; Salzberg, S.L. Fast gapped-read alignment with Bowtie 2. Nat. Methods 2012, 9, 357-359. [CrossRef]

58. Ghosh, S.; Chan, C.-K.K. Analysis of RNA-seq data using TopHat and Cufflinks. In Plant Bioinformatics. Methods in Molecular Biology; Edwards, D., Ed.; Humana Press: New York, NY, USA, 2016; Volume 1374, pp. 339-361.

59. Goff, L.A.; Trapnell, C.; Kelley, D. CummeRbund: Visualization and Exploration of Cufflinks High-Throughput Sequencing Data (R Package Version 2.8.2, 2014); Computer Science \& Artificial Intelligence Laboratory: Cambridge, MA, USA, 2014.

60. Thornton, B.; Basu, C. Real-time PCR (qPCR) primer design using free online Software. Biochem. Mol. Biol. Educ. 2011, 39, 145-154. [CrossRef] [PubMed]

61. Vargas, P.; Felipe, A.; Michán, C.; Gallegos, M.-T. Induction of Pseudomonas syringae pv. tomato DC3000 MexAB-OprM multidrug efflux pump by flavonoids is mediated by the repressor PmeR. Mol. Plant-Microbe Interact. 2011, 24, 1207-1219. [CrossRef]

62. Livak, K.J.; Schmittgen, T.D. Analysis of relative gene expression data using real-time quantitative PCR and the $2^{-\Delta \Delta C T}$ method. Methods 2001, 25, 402-408. [CrossRef]

63. Pfaffl, M.W. A new mathematical model for relative quantification in real-time RT-PCR. Nucleic Acids Res. 2001, 29, e45. [CrossRef]

64. Rotenberg, D.; Thompson, T.S.; German, T.L.; Willis, D.K. Methods for effective real-time RT-PCR analysis of virus-induced gene Silencing. J. Virol. Methods 2006, 138, 49-59. [CrossRef]

65. Fouts, D.E.; Abramovitch, R.B.; Alfano, J.R.; Baldo, A.M.; Buell, C.R.; Cartinhour, S.; Chatterjee, A.K.; D’Ascenzo, M.; Gwinn, M.L.; Lazarowitz, S.G.; et al. Genomewide identification of Pseudomonas syringae pv. tomato DC3000 promoters controlled by the HrpL alternative Sigma factor. Proc. Natl. Acad. Sci. USA 2002, 99, 2275-2280. [CrossRef] [PubMed]

66. Eichinger, V.; Nussbaumer, T.; Platzer, A.; Jehl, M.-A.; Arnold, R.; Rattei, T. EffectiveDB—updates and novel features for a better annotation of bacterial secreted proteins and type III, IV, VI secretion systems. Nucleic Acids Res. 2015, 44, D669-D674. [CrossRef]

67. Kearse, M.; Moir, R.; Wilson, A.; Stones-Havas, S.; Cheung, M.; Sturrock, S.; Buxton, S.; Cooper, A.; Markowitz, S.; Duran, C.; et al. Geneious Basic: An integrated and extendable desktop software platform for the organization and analysis of sequence data. Bioinformatics 2012, 28, 1647-1649. [CrossRef] [PubMed]

68. El-Gebali, S.; Mistry, J.; Bateman, A.; Eddy, S.R.; Luciani, A.; Potter, S.C.; Qureshi, M.; Richardson, L.J.; Salazar, G.A.; Smart, A.; et al. The Pfam protein families database in 2019. Nucleic Acids Res. 2018, 47, D427-D432. [CrossRef] [PubMed]

69. Söding, J.; Biegert, A.; Lupas, A.N. The HHpred interactive Server for protein homology detection and structure prediction. Nucleic Acids Res. 2005, 33, W244-W248. [CrossRef] [PubMed]

70. Castañeda-Ojeda, M.P.; Moreno-Pérez, A.; Ramos, C.; López-Solanilla, E. Suppression of plant immune responses by the Pseudomonas savastanoi pv. savastanoi NCPPB 3335 type III effector tyrosine phosphatases HopAO1 and HopAO2. Front. Plant Sci. 2017, 8, 680. [CrossRef]

71. Castañeda-Ojeda, M.P.; López-Solanilla, E.; Ramos, C. Differential modulation of plant immune responses by diverse members of the Pseudomonas savastanoi pv. savastanoi HopAF type III effector family. Mol. Plant Pathol. 2017, 18, 625-634. [CrossRef]

72. Wang, J.; Shao, X.; Zhang, Y.; Zhu, Y.; Yang, P.; Yuan, J.; Wang, T.; Yin, C.; Wang, W.; Chen, S.; et al. HrpS is a global regulator on type III secretion system (T3SS) and non-T3SS genes in Pseudomonas savastanoi pv. phaseolicola. Mol. Plant-Microbe Interact. 2018, 31, 1232-1243. [CrossRef]

73. O'Neill, E.M.; Mucyn, T.S.; Patteson, J.B.; Finkel, O.M.; Chung, E.-H.; Baccile, J.A.; Massolo, E.; Schroeder, F.C.; Dangl, J.L.; Li, B. Phevamine A, a small molecule that suppresses plant immune responses. Proc. Natl. Acad. Sci. USA 2018, 115, E9514-E9522. [CrossRef]

74. Solovyev, V.; Salamov, A. Automatic Annotation of Microbial Genomes and Metagenomic Sequences; Nova Science Publishers: New York, NY, USA, 2011.

75. Taboada, B.; Estrada, K.; Ciria, R.; Merino, E. Operon-mapper: A web server for precise operon identification in bacterial and archaeal genomes. Bioinformatics 2018, 34, 4118-4120. [CrossRef]

76. Alfano, J.R.; Collmer, A. Type III secretion system effector proteins: Double agents in bacterial disease and plant defense. Annu. Rev. Phytopathol. 2004, 42, 385-414. [CrossRef] [PubMed] 
77. Vinatzer, B.A.; Teitzel, G.M.; Lee, M.-W.; Jelenska, J.; Hotton, S.; Fairfax, K.; Jenrette, J.; Greenberg, J.T. The type III effector repertoire of Pseudomonas syringae pv. syringae B728a and its role in survival and disease on host and non-host plants. Mol. Microbiol. 2006, 62, 26-44. [CrossRef] [PubMed]

78. Shan, L.; Thara, V.K.; Martin, G.B.; Zhou, J.-M.; Tang, X. The Pseudomonas AvrPto protein is differentially recognized by tomato and tobacco and is localized to the plant plasma membrane. Plant Cell 2000, 12, 2323-2337. [CrossRef]

79. Vencato, M.; Tian, F.; Alfano, J.R.; Buell, C.R.; Cartinhour, S.; DeClerck, G.A.; Guttman, D.S.; Stavrinides, J.; Joardar, V.; Lindeberg, M.; et al. Bioinformatics-enabled identification of the HrpL regulon and type III secretion system effector proteins of Pseudomonas syringae pv. phaseolicola 1448A. Mol. Plant-Microbe Interact. 2006, 19, 1193-1206. [CrossRef]

80. Ferreira, A.O.; Myers, C.R.; Gordon, J.S.; Martin, G.B.; Vencato, M.; Collmer, A.; Wehling, M.D.; Alfano, J.R.; Moreno-Hagelsieb, G.; Lamboy, W.F.; et al. Whole-genome expression profiling defines the HrpL regulon of Pseudomonas syringae pv. tomato DC3000, allows de novo reconstruction of the Hrp cis element, and identifies novel coregulated genes. Mol. Plant-Microbe Interact. 2006, 19, 1167-1179. [CrossRef]

81. Lan, L.; Deng, X.; Zhou, J.; Tang, X. Genome-wide gene expression analysis of Pseudomonas syringae pv. tomato DC3000 reveals overlapping and distinct pathways regulated by hrpL and hrpRS. Mol. Plant-Microbe Interact. 2006, 19, $976-987$. [CrossRef] [PubMed]

82. Petnicki-Ocwieja, T.; van Dijk, K.; Alfano, J.R. The hrpK operon of Pseudomonas syringae pv. tomato DC3000 encodes two proteins secreted by the type III (Hrp) protein secretion system: HopB1 and HrpK, a putative type III translocator. J. Bacteriol. 2005, 187, 649. [CrossRef]

83. Charity, J.C.; Pak, K.; Delwiche, C.F.; Hutcheson, S.W. Novel exchangeable effector loci associated with the Pseudomonas syringae hrp pathogenicity island: Evidence for integron-like assembly from transposed gene cassettes. Mol. Plant-Microbe Interact. 2003, 16, 495-507. [CrossRef] [PubMed]

84. Teper, D.; Burstein, D.; Salomon, D.; Gershovitz, M.; Pupko, T.; Sessa, G. Identification of novel Xanthomonas euvesicatoria type III effector proteins by a machine-learning approach. Mol. Plant Pathol. 2016, 17, 398-411. [CrossRef] [PubMed]

85. Jalali, A.; Alavi, S.M.; Sangtarash, M.H. Comparative genomic analysis of wide and narrow host range Strains of Xanthomonas citri subsp. citri, showing differences in the genetic content of their pathogenicity and virulence factors. Australas. Plant Pathol. 2017, 46, 49-61. [CrossRef]

86. An, S.-Q.; Potnis, N.; Dow, M.; Vorhölter, F.-J.; He, Y.-Q.; Becker, A.; Teper, D.; Li, Y.; Wang, N.; Bleris, L.; et al. Mechanistic insights into host adaptation, virulence and epidemiology of the phytopathogen Xanthomonas. FEMS Microbiol. Rev. 2019, 44, 1-32. [CrossRef] [PubMed]

87. Moreira, L.M.; Almeida, N.F.; Potnis, N.; Digiampietri, L.A.; Adi, S.S.; Bortolossi, J.C.; da Silva, A.C.; da Silva, A.M.; de Moraes, F.E.; de Oliveira, J.C.; et al. Novel insights into the genomic basis of citrus canker based on the genome Sequences of two strains of Xanthomonas fuscans subsp. aurantifolii. BMC Genom. 2010, 11, 238. [CrossRef]

88. McNally, R.R.; Toth, I.K.; Cock, P.J.; Pritchard, L.; Hedley, P.E.; Morris, J.A.; Zhao, Y.; Sundin, G.W. Genetic characterization of the HrpL regulon of the fire blight pathogen Erwinia amylovora reveals novel virulence factors. Mol. Plant Pathol. 2012, 13, 160-173. [CrossRef]

89. Jones, A.M.; Wildermuth, M.C. The phytopathogen Pseudomonas syringae pv. tomato DC3000 has three high-affinity ironscavenging systems functional under iron limitation conditions but dispensable for pathogenesis. J. Bacteriol. 2011, 193, 2767-2775. [CrossRef]

90. Braun, V.; Braun, M. Iron transport and signaling in Escherichia coli. FEBS Lett. 2002, 529, 78-85. [CrossRef]

91. Miller, M.B.; Bassler, B.L. Quorum sensing in bacteria. Annu. Rev. Microbiol. 2001, 55, 165-199. [CrossRef]

92. Rutherford, S.T.; Bassler, B.L. Bacterial quorum sensing: Its role in virulence and possibilities for its control. Cold Spring Harb. Perspect. Med. 2012, 2. [CrossRef]

93. Mukherjee, S.; Bassler, B.L. Bacterial quorum sensing in complex and dynamically changing environments. Nat. Rev. Microbiol. 2019, 17, 371-382. [CrossRef] [PubMed]

94. Caballo-Ponce, E.; Meng, X.; Uzelac, G.; Halliday, N.; Cámara, M.; Licastro, D.; Passos da Silva, D.; Ramos, C.; Venturi, V. Quorum sensing in Pseudomonas savastanoi pv. savastanoi and Erwinia toletana: Role in virulence and interspecies interactions in the olive knot. Appl. Environ. Microbiol. 2018, 84, e00950-18. [CrossRef]

95. Strobel, G.A. Bacterial phytotoxins. Annu. Rev. Microbiol. 1977, 31, 205-224. [CrossRef]

96. Bender, C.L.; Alarcón-Chaidez, F.; Gross, D.C. Pseudomonas syringae phytotoxins: Mode of action, regulation, and biosynthesis by peptide and polyketide Synthetases. Microbiol. Mol. Biol. Rev. 1999, 63, 266-292. [CrossRef] [PubMed]

97. Sreedharan, A.; Penaloza-Vazquez, A.; Kunkel, B.N.; Bender, C.L. CorR regulates multiple components of virulence in Pseudomonas syringae pv. tomato DC3000. Mol. Plant-Microbe Interact. 2006, 19. [CrossRef] [PubMed]

98. Oh, C.S.; Kim, J.F.; Beer, S.V. The Hrp pathogenicity island of Erwinia amylovora and identification of three novel genes required for systemic infectiondouble dagger. Mol. Plant Pathol. 2005, 6, 125-138. [CrossRef] [PubMed] 